Getting Organized 



\section{Getting Organized}

Business Organization and Succession Planning for Oregon Family Farms and Ranches

CHRISTY ANDERSON BREKKEN AND JOE HOBSON

OREGON STATE UNIVERSITY

CORVALLIS, OR 


\section{(ㅇ) (1) $\circledast \odot$}

Getting Organized by Christy Anderson Brekken \& Joe Hobson is licensed under a Creative Commons Attribution-NonCommercial-NoDerivatives 4.0 International License, except where otherwise noted.

Publication and ongoing maintenance of this textbook is possible due to grant support from Oregon State University Ecampus.

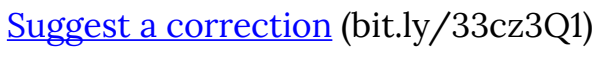

Privacy (open.oregonstate.education/privacy)

This book was produced with Pressbooks (https://pressbooks.com) and rendered with Prince. 


\section{Contents}

Introduction to Farm Succession Planning

Chapter 1: Take Care of the Family

Chapter 2: Ensure the Financial Health of the Farm Business

A. Farm Business Financial Viability

1. Determine the Farm's Income Needs

2. Determine the Farm's Value

3. Calculate the Farm's Rate of Return

4. Increase the Rate of Return

5. Value and Incorporate Gen 3 Skills

6. Increase the Operating Capital

7. Convert Farm Assets into Retirement Income or Operating Capital

B. Managing Risk for the Health of the Farm Business

1. Obtaining Insurance to Manage Risk

2. Managing the Risk of Not Getting Paid

Chapter 3: Organize the Farm Business Limited Liability Company (LLC)

A. Why Form a Business Entity Under State Law?

B. Choosing a Business Entity

C. Forming an LLC

D. Operating an LLC

E. LLCs for Succession Planning

Chapter 4: Organize Your Farm LLCs for Your Business Succession Plan

A .Motivations and Goals for the Last-Person-Standing LLC Structure

B. Create the Last-Person-Standing LLC Structure

1. Form an Operating LLC

2. Form Asset-Holding LLCs

C. Make the Pie Bigger: Gen 3 Business Entities

D. Connect the Farm LLCs with Leases and Contracts

Chapter 5: Create the Estate Plan
A. Wills
B. Trusts
C. Tax Planning
1. Estate Taxes
2. Estate Tax Planning Strategies
D. Liquidity 
Chapter 6: Putting It All Together: Business Succession and Estate Planning for the Long Haul

A. Make the Current and Long-Term Farming Decisions, the Succession Plan, and the Estate Distribution Plan Work Together

B. How Getting Organized Can Help the Farm and Family Weather Disruptive Life Events

1. Death

2. Divorce

3. Bankruptcy

4. Withdrawal

5. Providing Opportunity for a Family Member to Buy Back In

6. Risk Management

7. Integrating Gen 3

C. Lessons Learned

Resources

Checklist for Farm Business Succession Planning

Glossary 


\section{About the Authors}

Disclaimer: This guide is intended for general educational and informational purposes only, in conjunction with other resources on the subject. This guide does not provide legal advice or establish an attorney-client relationship between the reader and authors. Always consult an attorney together with competent tax and financial advisors regarding your specific situation prior to taking any steps.

Acknowledgments: We are grateful to Open Oregon State for their support in developing this handbook and making it freely available. We also thank Schwabe, Williamson \& Wyatt for support in the development and wider distribution of this handbook at this critical time in Oregon agriculture.

We are also indebted to the colleagues who have worked on farm succession planning with us throughout the years and reviewed this handbook, providing thoughtful insights and suggestions. Our thanks go to Nellie McAdams, attorney, Oregon Agricultural Land Trust; Ashley Rood, farm preservation program director, Rogue Farm Corps; Matt Bisturis, attorney, Schwabe, Williamson \& Wyatt; Maria Schmidlkofer, attorney, Schwabe, Williamson \& Wyatt; Dave Buck, CPA, Aldrich CPAs and Advisors LLP; Sherri Noxel, OSU Austin Family Business Program; and Bart Eleveld, OSU Department of Applied Economics.

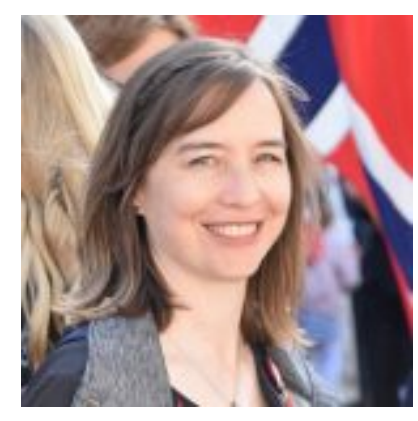

Christy Anderson Brekken, M.S., J.D., is faculty member in the Department of Applied Economics at Oregon State University, where she prepares the next generation of agricultural leaders to enter the field by teaching courses on agricultural law and environmental policy. Ms. Brekken has also developed and presented farm succession planning workshops throughout the state in collaboration with colleagues at Oregon State University. Her research includes The Future of Oregon's Agricultural Land, a report on the transition of Oregon's natural resource lands to the next generation. She holds a M.S. in Agricultural and Resource Economics from Oregon State University, and a J.D. from University of Minnesota. 


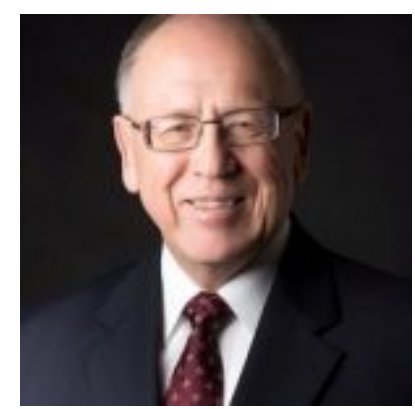

Joe Hobson, J.D., is a shareholder at Schwabe, Williamson, \& Wyatt with an office in Salem, Oregon. He has been practicing business and organization law for 40 years, with a focus on helping family farms, ranches, and forest owners in their business organization. Mr. Hobson has also been integral in Oregon's agricultural landscape through his work with nonprofits and special districts that focus on agricultural interests. He was the Oregon Farm Bureau's first general counsel, and helped to develop the Oregon Agricultural Education Foundation and the Oregon Agricultural Legal Foundation. Mr. Hobson has helped many Oregon family farms and ranches develop and implement their business organization and succession plans, and he now presents at workshops around the state to educate and empower producers to take the next steps to pass their legacy on to the next generation. He holds a J.D. from Willamette University College of Law. 


\section{Introduction to Farm Succession Planning}

Every farm, ranch, nursery, dairy, or other agricultural operation is more than a business. It is a connection to family and tradition and provides essential food, fiber, fuel, and other benefits for society. But without attention to the farm as a business, it will not survive into the future or continue to provide those important connections and services. A farm's management succession and estate planning are often uncomfortable topics for everyone involved. However, they are essential to protect and extend the agricultural operation.

The purpose of this guide is to provide foundational education for farm and ranch families on how to create a basic business succession and estate plan. In working with farm families, we have identified four fundamental goals for the farm succession planning process: (1) preserving family relationships, (2) strengthening the farm business, (3) protecting the owners and Four Fundamental Goals for Farm Succession Planning

1. Preserving family relationships

2. Strengthening the farm business

3. Protecting owners and operators from business disruptions

4. Minimizing complexity and expense operators from business disruptions, and (4)

minimizing the complexity and expense of succession and estate plans. With some basic knowledge, you will be educated consumers of legal and financial services, which may save you time and money as you consult with the attorneys, accountants, and other professionals who are key to creating a successful plan. This guide also gives you a starting point as you consider your alternatives and begin family discussions about the roles that each family member or nonfamily member may play in the future of the farm as a business.

Throughout this guide, the terms farm and farmland include ranches, dairies, nurseries, or other agricultural operations. Oregon agriculture is incredibly diverse, with more than 220 different products grown and sold across the globe, which is one of the strengths of the sector that is worth

preserving. Farm succession and estate planning are important for all agricultural operations. The information provided here will assume the farm is in Oregon. There are many differences among states when it comes to taxes and regulation. And though some of the specifics included here may not apply in other states, the basic motivation and planning steps are universal.

Business and Estate Planning Team
Throughout this guide, we will also refer to the three generations involved in the farm business (figure 1). Generation (Gen) 1 is the "grandparent" generation. Those in this 


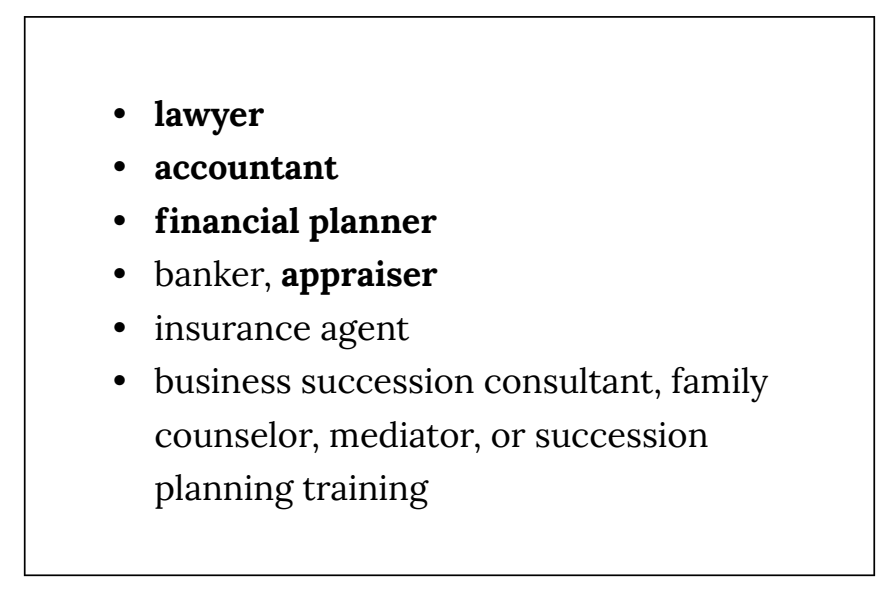
dynamics are as important as the business balance sheets. Nonfarming family members can feel satisfied with the process by being included and receiving meaningful gifts that do not need to have the same monetary value as the business interests or gifts received by the farming family members. Everyone must feel included in the family legacy, but not everyone has to (or should) have control of the farm business.

\section{Overlapping Generations in Farm Business Management}

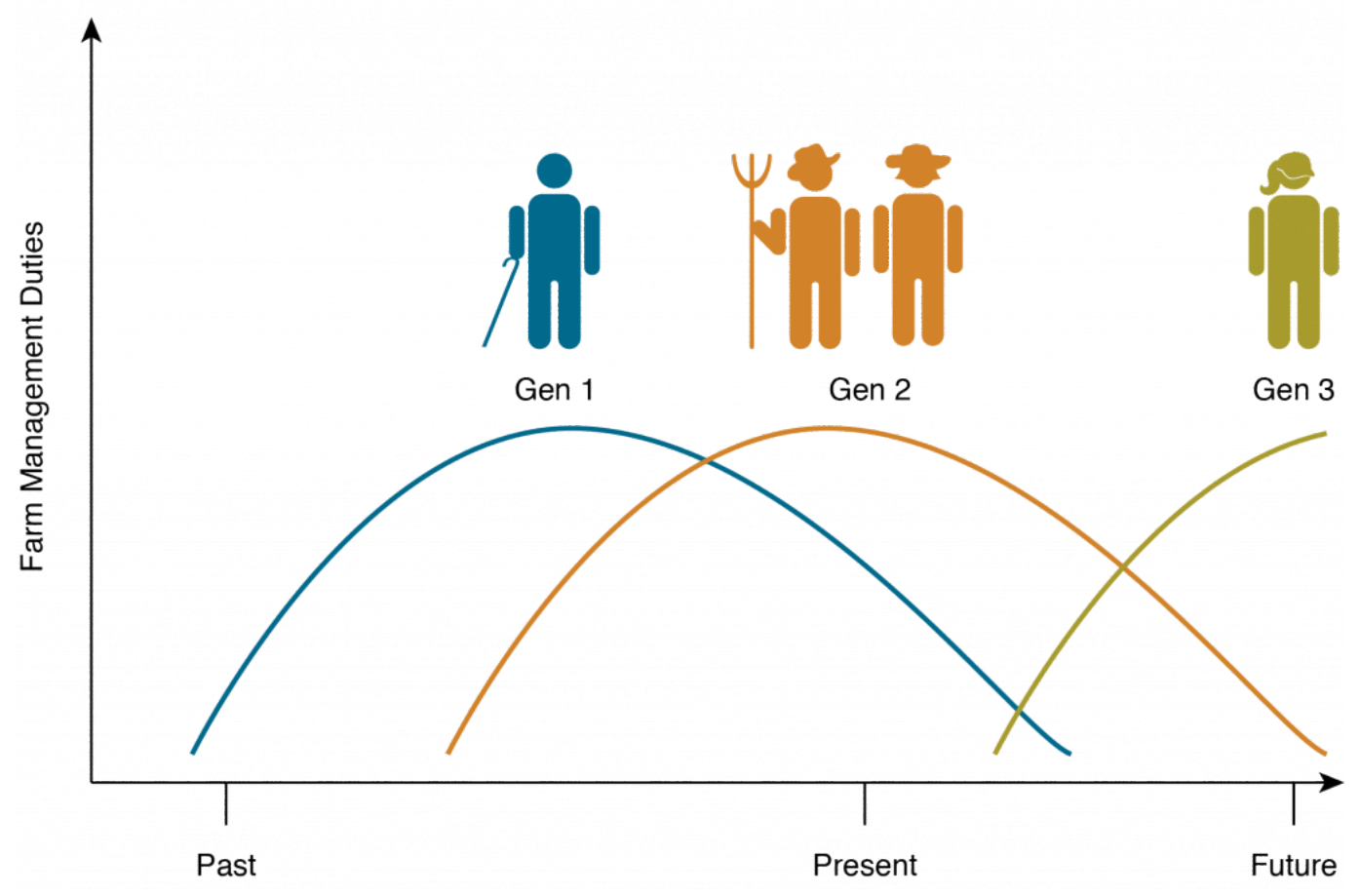

Figure 1. Overlapping generations in farm business management

Today, many Gen 1 and Gen 2 farm owners and operators do not have a Gen 3 member generation are in their retirement age but often still own and may still be actively involved in the operation. Gen 2 is the "parent" generation. They may be actively involved in the farm operation and are planning for retirement soon. Gen 3 is the "child" generation. They are typically young adults who are in college or are recent college graduates and are determining a career path. It is also crucial to include the nonfarming family members in the business succession and estate planning because family 
in the family who wants to come back to the farm, so the owners may be looking for nonfamily successors to take on management duties. While an outright sale of the farm to a new operator might seem like the only option, it is often not in the best interest of the farm, the retiring generation, or beginning farmers. Management and ownership successions give the retiring generation a chance to pass on their knowledge and maintain long-term business relationships that benefit the farm and the new farmer in the long run. Management succession also allows the retiring generation to draw ongoing income from the farm rather than receive a lump sum in a sale, which may undervalue the farm as an ongoing operation. Likewise, many Gen 3s who are studying agriculture and agricultural business management in college today do not have a family farm to "go back" to, but they aspire to own their own farm. Because of land prices, student loans, and other expenses, buying a farm or starting a new operation outright is out of the question for young farmers without family land or significant capital. There are fruitful relationships that can be developed with nonfamily successors. We will pay special attention to the considerations of nonfamily succession planning for both Gen 2 operators considering including a nonfamily Gen 3 individual in their business succession plan and potential nonfamily Gen 3 successors.

Whether the incoming generation is family or not, business succession planning requires a clear articulation of shared goals and plans, immaculate documentation, and attention to detail. When expectations and plans are well defined, people can feel secure about the future of the business and their place in it. It is sometimes assumed that a succession plan will unfold naturally as the generations work together to manage the farm, but it is important to create expectations and plans that everyone agrees to abide by. Clarifying roles and responsibilities does not imply that the elder generation distrusts the younger generations; rather, early planning can give everyone clarity, confidence, and increased family harmony. It also opens lines of communication so that if circumstances change, there is a basis for reopening the conversation and changing the plan.

It is also critically important that the farm business is viable, meaning that it is generating a reasonable rate of return as an ongoing agricultural operation. It must have value and the potential to continue to create income for the owners and operators into the future. By

Bringing a new generation into the operation means new skills, ideas, and labor that are assets to the business-and more people that need to be paid out of the business returns. bringing a new generation into the operation, you are bringing in new skills, ideas, and labor that are assets to the business. However, you are also bringing in more people that need to be paid out of the business returns. The goal of a successful succession plan is not to give more people a smaller slice of the pie but to make the pie bigger (figure 2). That goal needs to be a key element in the planning process so that the incoming generation has a living wage and the retiring generation can take out money for their household and healthcare needs after they leave the day-to-day management of the business. A business can become stronger through the focused attention and development required in a succession planning process. 


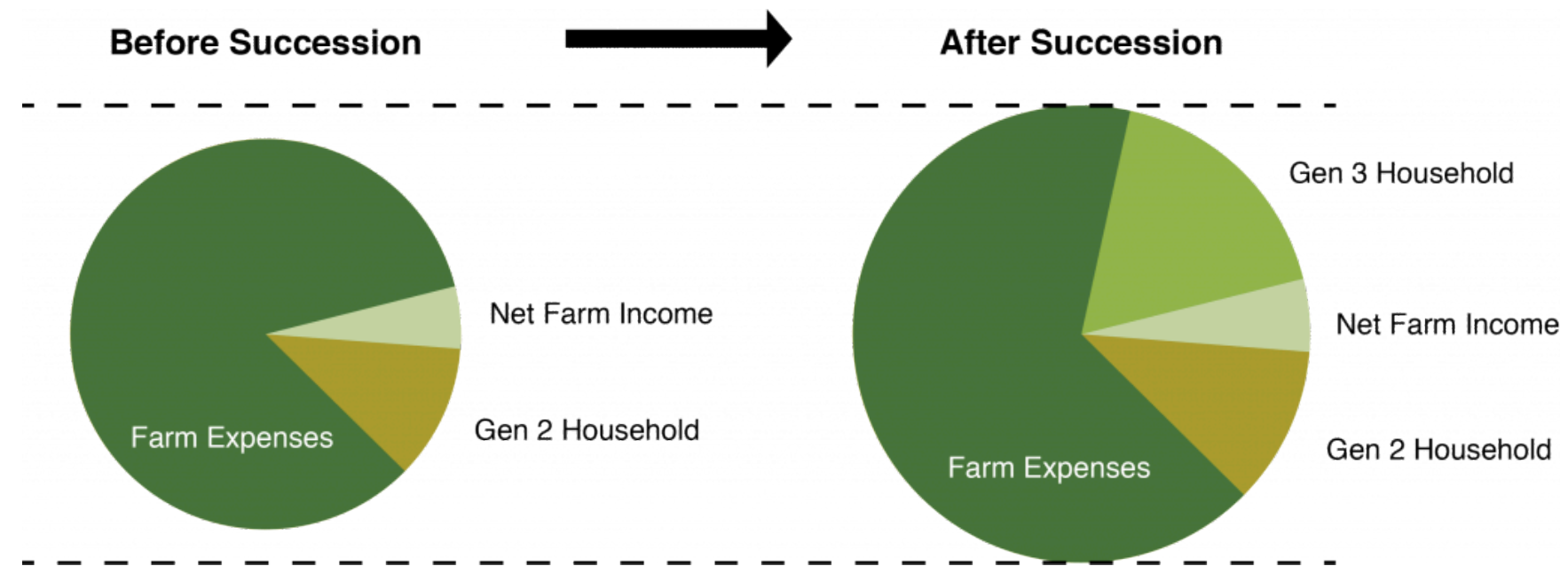

Figure 2. Increasing farm income for succession planning

While the goal is a successful business succession, which allows Gen 2 to retire and Gen 3 to enter farm business management, things do not always go as planned. Agricultural businesses face many risks, such as increases in the cost of inputs, decreases in farm product prices, natural disasters, changing regulations and trade relations, family illnesses, legal liabilities, interest rate changes, land development pressures, and others. The goal of business succession planning is not only to strengthen the business but to protect the people and assets involved in the business if things fall apart. For example, if one of the farm's business lines is hit with a devastating shock, the land and other assets need to be protected. Just as buildings in an earthquake-prone area are built to withstand the shock or fall apart in a way that protects the occupants, we must create a business plan that protects valuable assets that are necessary for the farm and provides a road map for sorting out the various and sometimes competing interests of the family members if a shock hits the farm.

Finally, we want to create a plan that is manageable for the people who are living with it. While the structure will likely be more complex than a sole proprietorship, the administration of the plan must be understandable and sustainable so that the people involved can go about running the farm, not managing the business structure. The same can be said for other aspects of estate planning, such as managing taxes and trusts. While we plan to minimize taxes, the strategies cannot be so complex that they are unmanageable or create other types of risks. We can use common, existing tools for planning and develop relationships with trusted professionals, such as an attorney and accountant, who help the farm owners keep things on track.

This guide is organized to give you an overview of how to pass the family farm on to a new generation. The goal is to preserve family relationships, tune up the farm business to be successful today, smoothly pass the farm to the next generation as the current operators retire, and take care of the whole family when the older generations pass away. There are five distinct but interlocking pieces to this process: (1) take care of the family, (2) ensure the financial health of the business, 
(3) organize the farm business limited liability company (LLC), (4) organize the farm LLCs for the business succession plan, and (5) create the estate plan. All five steps can happen simultaneously in the planning process or can be picked up and revised at any time as circumstances change.

\section{Step 1-Take care of the family}

We are focused on the nuts and bolts of business succession and estate planning, but the purpose of all of this is taking care of your family. Generations have built up your family farm, and you have a legacy to pass on to today's and tomorrow's generations. If you are Gen 1 or 2 , start by letting your family know that you are thinking about what will happen to the farm and family after you retire or die and that taking care of them and the farm is your priority. It's never too early to start! Thinking carefully about your goals, who will manage the farm, and your family's wishes will be the foundation for conversations with your estate and business lawyers. If you are Gen 3, you will want to communicate your commitment to continuing the farm legacy and your timeline and open lines of communication about management succession.

The future of your family and farm is the best motivation for getting started, and getting started immediately may inspire you to move deeper into the planning process. Every family is unique, and you are the only one who can begin your business succession and estate distribution plan.

\section{Step 2-Ensure the financial health of the farm business.}

Ensuring business viability involves the analysis of the business's income, rate of return, operating capital, and risk management. In this process, managers may need to change aspects of the farm to increase the rate of return to accommodate incoming generations. We recommend increasing the rate of return because the goal of business succession is not to give more people a smaller slice of the pie but to make the pie bigger in the planning process. A strong business is a candidate for a successful business succession process, and the business can become stronger through the focused attention and development in the business succession planning process.

\section{Step 3-Organize the farm business limited liability company (LLC).}

While planning to improve the farm's financial position and risk management, you will work on getting the farm business organized in such a way that it will facilitate the succession plan. We will discuss legal business entities and how to organize a business for optimal risk management in the present, regardless of whether the business succession plan is put into action immediately or in the next decade.

\section{Step 4-Organize your farm LLCs for your business succession plan.}


Next, you will develop a business succession plan for the farm, with the estate distribution plan in mind. This will involve business organization steps building from the foundation established in step 3. The succession plan establishes the timelines, milestones, and processes for bringing Gen 3 into management and then ownership of the farm while Gen 2 retires.

\section{Step 5-Create the estate plan.}

The business succession plan gives Gen 2 peace of mind, knowing that the farm will continue on as a legacy of their hard work. We circle back to the distribution plan created in step 1, using legal tools such as wills and trusts while planning for taxes and other expenses that can threaten the value that you want to pass on to your family.

We finish this guide with some general observations on how creating your business succession and estate plan can help the farm and family weather common disruptive life events, such as death, divorce, debt, and other risks. The ultimate goal is to provide all family members with realistic expectations and peace of mind, knowing that everyone's unique interests are considered during some of life's most challenging times. 


\section{Chapter I: Take Care of the Family}

Gen 1 and 2 (and generations past) built the farm to take care of the family. While we are focused on business succession planning, the ultimate purpose is to keep the family together. A good business plan can minimize family tensions by setting up clear roles and expectations, clarifying the business relationships to allow the family relationships to thrive. A good estate plan ensures that everyone is treated equitably, not necessarily the same or equally, because each family member is unique.

Prior to setting up business entities and estate planning, it is important to have open, honest conversations with family members. It starts with letting everyone know that you are thinking about the long-term operation of the farm after you retire or die, and it is never too early to start those conversations. Even new farmers should think about what will happen to the farm and family if the unthinkable happens. You can share your goals for the future of the farm and find out what family members want in their relationship to the farm.

We also start with the family because the business succession plan needs to be driven by Gen 2's estate distribution plan, which is the outline for who gets what when Gen 2 (and/or Gen 1 , if applicable) passes away. This means that you should consider your broad estate planning first. To develop a distribution plan, Gen 2 should create a list of all their personal and business assets alongside a list of everyone who will get a bequest. At this point, it would be a broad outline, such as "The most important thing is for the farm to pass on to the next generation when I die," "I want child A to end up with the farm," "I want child $\mathrm{M}$ to get the china and child $\mathrm{N}$ to get our wedding rings," or "I want to leave a donation to our church." A distribution plan doesn't need to be much more complicated than that at this point. This is a good time to talk with your family to find out which gifts will be meaningful or helpful to them. Don't assume you know what your family members truly want! These conversations can be very illuminating for many families. The best way to honor your family members is to give them gifts that are meaningful. Giving individualized gifts recognizes the special relationship you have with each member of your family.

This is a great time to sit down and start your estate distribution plan because it can proceed without any more instructions. The future of your family and farm is the best motivation for getting started, which then may inspire you to move deeper into the planning process. Every family is unique, and you are the only one who can begin your estate distribution plan.

You should also be actively engaged in finding a Gen 3 successor from within or outside of the family. The lack of a family successor is a major stress for many of today's farms. Today, the average age of Oregon farmers and ranchers is around sixty years old, and many do not have a family member in the next generation who wants to come back to manage the farm. Hence, finding a nonfamily successor is becoming necessary for many farms. Meanwhile, many young

people are training to go into agriculture but do not come from a farming family and are looking 
for opportunities to enter a career in agriculture. Preparing your family for a nonfamily successor is an important conversation. You may also work with multiple potential successors until you find one that is right for the long term. Your potential successor may start out as an employee, move into management duties, take over management, and finally take ownership interests in the farm. You will want time to find and train potential successors until the right person comes along, understanding that not everyone who trains with you will work out.

Finally, getting an idea about your goals, your successor, and your family's wishes will be the foundation for conversations with your estate and business lawyers. Your goals for the future and your family's expectations will impact the way you structure your business organizations, succession plans, and estate plans. As you go through this process, expect that it will take significant time, effort, and expense. It's a lot cheaper to work with your family by hosting family meetings or participating in farm succession trainings than it is to work out all of these details in your lawyer's or accountant's office. By starting the process with your family, armed with knowledge about your options, you will save time and money in the long run.

\section{Step 1-Take care of the family by gathering ideas and expectations.}

- Let everyone know that you are thinking about the long-term operation of the farm after you retire or die.

- Talk to your family about your estate plan. Find out how family members would prefer to be recognized in your estate plan. Start establishing expectations about the business succession and estate plan well before it is drafted.

- Discuss farm succession with family members who express an interest in managing the farm to assess their level of commitment and expectations and involve them in the decisionmaking process.

- If you do not have a Gen 3 successor in the family, seek out Gen 3s that would be a good fit by networking with other farmers, connecting with local or state agricultural education programs such as those at Oregon State University, or connecting with other organizations that manage farm training or young farmer programs.

- If you do not have a Gen 3 successor, set up an internship or limited farm manager position as an introductory period with no long-term commitments. You may need to work with several potential successors before you find the right fit. Use the process to plan and practice turning over management tasks to as well as training an incoming Gen 3.

- Identify professionals that can help you through the process. Start with any professionals that you already work with, ask for referrals if you need to find other experts, and get advice from lenders and other farmers.

- Attend a business succession workshop or seminar and explore further business succession resources. 


\section{Chapter 2: Ensure the Financial Health of the Farm Business}

The second step in the business succession planning process is to evaluate and tune up the farm's financial situation. We will accomplish that through an analysis of the farm's ability to support multiple generations during the transition process. We will review the farm's income needs, value, rate of return, operating capital, and risk-management strategies.

\section{A. Farm Business Financial Viability}

The first piece of business succession planning is making sure that the farm business is currently economically viable with a reasonable rate of return and developing a plan to expand the business so that it can support both the new generation and the retiring generation. The retiring generation has worked their whole life to build the business and should expect the business to continue to support them into retirement. The new generation brings new skills, ideas, and labor that are assets to the business, but they also need to be paid out of the business returns. The goal is not to give more people a smaller slice of the pie but to make the pie bigger in the planning process. A successful business succession process starts with a strong business. The business succession planning process should include making the business stronger as well.

\section{Determine the Farm's Income Needs}

For a viable working farm, a substantial part of the family's household income is coming from the farm. Most farms also have off-farm income from a spouse, which may also provide medical or other insurance. When Gen 2 retires from operating the farm, their expenses will change. If a spouse with an off-farm job retires, that will

A financial planner and accountant can help you prepare for retirement through budgeting household income needs and understanding retirement accounts, pensions, Social Security, Medicare, and other sources of income and support. reduce the family income and add new expenses, such as medical insurance or others. When Gen 2 retires, each person may draw from Social Security, retirement accounts, or pensions from off-farm jobs to supplement their income. 
Their tax situation will also change with a decrease in income and no business deductions for on-farm housing or business vehicle expenses. Retirement brings big financial changes, and Gen 2 will have to carefully budget the farm income to provide for their own retirement in addition to Gen 1s who are still supported by the farm. A financial planner and the family accountant can be extremely helpful in preparing for retirement, from budgeting to understanding retirement accounts, pensions, Social Security, Medicare, and other potential sources of personal income or support and expense.

The incoming Gen 3 operators may also have an off-farm source of household income but should also be able to expect the farm to provide a substantial part of their income, especially as they start a family and that family grows. If Gen 3 becomes the new farm operator and moves to the farm, housing costs may be required to support a new household, whether that be adding housing to the current land or one generation moving into other housing. Gen 3's household budget likely looks different from Gen 2's budget and requires a fair market wage from a viable farm business.

It is essential to recognize that the farm will be expected to support more people in the future, which will require a fair accounting of the farm's current value, the rate of return on farm assets and cash flow, and the other assets owned by Gen 1 and Gen 2 that can provide for their retirement. The succession planning must consider how farm assets can be managed in a way that supports both Gen 1's and Gen 2's retirement needs-which may come from the farm income-Gen 3's household income needs, and the farm's ongoing capital and cash flow needs. An honest accounting will show that the farm will have to increase its income in order to support all of these objectives, which will make it a stronger business (figure 3).

Before Succession

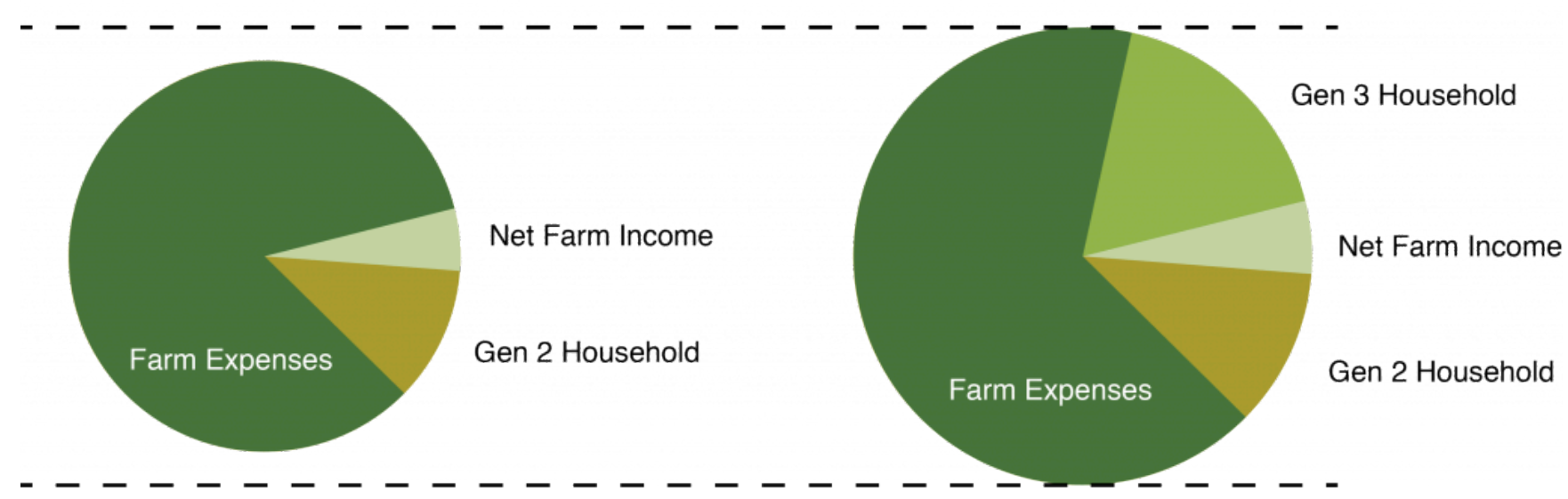

Figure 3. Increasing farm income for succession planning 


\section{Determine the Farm's Value}

It is critical to find out what the farm is worth and the farm owner's total assets. This inventory is useful for business valuation, estimating estate taxes for further planning, and understanding everything that is available to include in the estate plan, which provides for meaningful gifts for all family members whether or not they plan to be involved in the farm business. To create an estate plan for the business owners, we also must inventory their personal assets.

A farm is a business. A business is worth what you can sell it for. A sale of a business is based on the value of its assets: real property, personal property, and the business's value as an economically viable unit. An agricultural business with its own brand, such as a successful winery or a processed-foods company, may have additional value due to its brand name, future contracts, and reputation. A farm's financial performance must promise the safety of capital contributions and an adequate return. Otherwise, the operation is only a speculative economic unit, not a secure financial investment for the incoming generation. Here we will look at the present value of the farm, and in the next section, we will address its rate of return.

For the most part, the only asset typically used to value a farm at any given point in time is the land, timber, or other land-based assets because equipment and other property depreciate quickly. Livestock operations, such as dairies and cow-calf operations, also have notable value in the herd. If the farm is already organized as a business entity (an LLC or corporation), the value of the business should be determined based on what the business owns. However, because the vast majority of Oregon's agricultural businesses are still owned as sole proprietorships or partnerships, the land, equipment, livestock, and other assets are technically owned by the operators personally. To organize the business, we must inventory the business assets.

With respect to the land, we want to know how much there is, where it is located, and the current fair market value. We also want to know whether it is owned or rented. Quite often in today's modern farming operation, less than half of the land being farmed is owned by the family doing the farming. For the land that is owned, we want to know how much that land is worth on a true fair market basis. In other words, if a piece of the land was put up for sale today, how much would a willing, knowledgeable buyer actually pay for it? The assessed value is often not the best measure of the current value; the best way to determine true market value is to use comparable sales in the area rather than a formal appraisal. Often a knowledgeable realtor in the area can help by providing an estimate of what the land can be sold for at its present market value. Such an estimate is generally called a comparable market analysis.

Farmers have to buy and operate a large amount of very expensive equipment because of the increase in productivity that the equipment brings to the operation. However, farm equipment begins to depreciate in value the moment it is driven away from the dealer. Investments in the latest equipment dwindle very quickly. In valuing livestock, we consider herd size, value, and the method used to keep track of animals as they come and go through the operation. For example, 
dairies often have herds of registered cows with certification of their genetic background. This makes a cow more valuable, and the reputation of the farmer becomes a part of the value of the animal. Each animal typically has a brand or ear tags to identify the background of the animal and its place of origin and to and distinguish it from the other members of the herd. For purposes of succession planning, auction houses in the area can help by providing an estimate of the sales price of equipment and livestock.

The farm owners may have other assets owned in their name, such as investment accounts (individual stocks, bonds, or mutual funds), cash or cash equivalents (checking accounts, savings accounts, money market accounts, certificates of deposit, etc.), security deposits, retirement accounts (401[k], IRA, SEP), annuities, life insurance, and other personal property such as vehicles, boats, airplanes, collectibles (value to a knowledgeable collector), and other personal property (valued at a farm sale or garage sale). In order to accomplish a successful succession plan, the professionals will need to know about and take into consideration all of these assets.

\section{Calculate the Farm's Rate of Return}

You will want to calculate the farm's rate of return to determine if the business is currently economically viable. Then you will have a baseline for developing a plan to expand the business so that it will have a reasonable rate of return to support both the new generation and the retiring generation. You will gather this information for your own business planning purposes if you are not already doing it regularly.

The most valuable asset of a farm is the land. The value of livestock is also a major asset for dairies and cow-calf operations. The rate of return for a farm's land or livestock is the net

gain or loss on the investment in the asset over a specified period, expressed as a percentage of the original investment. Gains on investments are defined as income received plus any capital gains realized on the sale of the investment. Although you are not planning to sell the assets, you will pick a date to calculate the rate of return on assets that you hold over a reasonable period. For ease of illustration, we will use a one-year period as an example. To calculate the rate of return for the land and/or the livestock over a one-year period, first determine the amount of the original investment in those assets. Next, determine the fair market value of those assets at the beginning and at the end of the most recent year. Next, calculate the net excess income (profit) or loss received from the farming operation that is using those assets to generate income. Net excess income is the amount that exceeds or falls below operating expenses excluding salaries, distributions, or draws paid to the owners.

For simplicity, let's say the original investment in the asset was $\$ 100,000$. The difference in the fair market value of the assets at the beginning of the year and the end of the year was $\$ 4,000$ (capital gain), while the operation enjoyed the net excess income of $\$ 3,000$ during the year.

6 | Chapter 2: Ensure the Financial Health of the Farm Business 
Add together the gain in value and the net excess income for the year, which comes to $\$ 7,000$. The annual rate of return on the investment for the one-year period is the increase in value plus the net excess income divided by the original investment in those assets. To calculate the rate of return from our example, the original investment is $\$ 100,000$, the increase in value plus the net excess income is $\$ 7,000$. Thus the annual rate of return on the investment is 7 percent $(\$ 7,000 /$ $\$ 100,000=0.07=7$ percent; table 1$)$.

Table 1. Rate of return on land example

\begin{tabular}{|c|c|c|c|c|c|}
\hline $\begin{array}{c}\text { Capital Gain Year 1 } \\
\text { (Market Value) }\end{array}$ & $\begin{array}{c}\text { Value End of Year } \\
\text { \$104,000 }\end{array}$ & - & $\begin{array}{c}\text { Value Start of Year } \\
\mathbf{\$} 100,000\end{array}$ & $=$ & $\mathbf{\$ 4 , 0 0 0}$ \\
\hline Net Income Year 1 & $\begin{array}{c}\text { Revenue attributed to } \\
\text { land }\end{array}$ & - & $\begin{array}{c}\text { Costs associated } \\
\text { with land }\end{array}$ & $=$ & $\mathbf{\$ 3 , 0 0 0}$ \\
\hline Total Return Year 1 & $\begin{array}{c}\text { Capital Gain } \\
\text { \$4,000 }\end{array}$ & + & $\begin{array}{c}\text { Net Income } \\
\text { \$3,000 }\end{array}$ & $=$ & $\mathbf{\$ 7 , 0 0 0}$ \\
\hline Rate of Return & $\begin{array}{c}\text { Total Return on Land } \\
\text { \$7,000 }\end{array}$ & $/$ & $\begin{array}{c}\text { Value Start of Year } \\
\text { \$100,000 }\end{array}$ & $=$ & $\mathbf{7 \%}$ \\
\hline
\end{tabular}

This example should demonstrate that a key part of determining whether a farming operation is a viable business is the net excess income being generated by the farm. Capital gains from increased asset values are not "realized" at the end of the year because you do not sell them. The farm continues to own them to generate income. The increased value of the land and cattle is locked in until they are sold; that value cannot be used by present operators to pay expenses or for the kids' college tuition unless you convert that asset to cash, which comes with risk and will be discussed later. Therefore, it is crucial to focus on generating adequate net excess income from the business when planning a farm succession.

For a farm that is an ongoing business, the gain in value of the hard assets (land and livestock) will hopefully be passed down to the next generation without ever being converted to cash or diminished. Whether that happens will depend in large part on if a successful business succession plan coupled with a well-designed and coordinated estate plan can be developed for the farm. It will also depend on whether market conditions and public policy are generally favorable or unfavorable to the farm over time.

For a farm to be a viable business, its rate of return must be equal to or greater than what you could expect to receive in fair market rent for that same asset under a triple-net cash lease, meaning rent payments minus taxes, insurance, and maintenance and adjusted by any mortgage payment if the land is not owned outright (table 2). In other words, in order for a farm to be a good prospect for succession planning, the farm should be making more money through the current 
or projected farming operation than it could make by renting the land and cattle out to another operator. The income generated from the land must cover all land expenses and then some to show a profit.

Table 2. Triple-net cash lease calculation

Real Estate Taxes

+ Property Insurance

+ Property Maintenance

+ Mortgage interest (if any)

= All Land Expenses

+ Expected return on land (2\%-5\%)

$=$ Minimum Annual Rental Payment

\section{Increase the Rate of Return}

For a farm operation to support the next generation, it is likely that the farm will have to increase its rate of return on investment, generating more farm income that can be paid as retirement income to Gen $2 \mathrm{~s}$ and household income to Gen 3s. As discussed, the key goal is to increase the net excess income from the business so that it can be paid as wages, bonuses, and benefits or reinvested in the business for future growth.

Each farm has its own unique path to increase the rate of return and thus requires a careful analysis of its current operations and future opportunities. However, there are a few general ideas to increase rate of return for current operations.

First, diversify the farm by finding new markets that pay higher prices for the products. Diversifying the farm's activities provides for different streams of income and expenses, which can also provide some risk management if markets change. This may come in the form of different marketing channels, such as going directly to retail, restaurants, schools, hospitals, or consumers.

Markets for local and regional foods, which could be anything grown in Oregon, often offer price premiums. Products can also be Ideas for increasing rate of return for your operation: differentiated by certifications, such as USDA- 
certified organic or other third-party certifications. Food processors in the region seek out certified organic products, and there is still higher demand than supply for products such as organic grains and nuts. There are also niche products, like specialty grains, that are in demand. Finally, some on-farm and value-added processing can allow you to sell products at higher prices. However, with all of these

- Diversify income streams through new markets, value-added processing, or certifications.

- Reduce cost of production after analysis of expenses or investing in new technology.

- Increase productivity by adding land, higher-value crops, or new business lines. opportunities come costs and risks, and the prices obtained must be higher than the costs associated with the differentiated products or markets. Some have high fixed costs, such as the three-year transition time to organic and certification fees, but if the costs can be covered in the long run for a consistently higher rate of return, the investments will be sound.

It's not a value-added product until I sell it and am paid for my efforts. Before then, it's cost added.

-Oregon farmer, pickle and jam producer
Another way to improve the bottom line while continuing with current production requires lowering the cost of production, which accountants refer to as the cost of goods sold. The first step is tracking your costs and returns for different farm business activities. If you have not moved beyond paper and pencil accounting, organizing your financial information using basic business accounting software or starting a relationship with an accountant is highly recommended. It will take time, effort, and money to get started, but it will save you headaches in the future and give you valuable information about managing your farm costs, revenues, and the economic viability of various crops or other business activities. You will have a clearer picture of which costs you can control; many costs of production, such as fuel, seed, fertilizer, pesticides, and other inputs, are outside of your control unless you switch practices. Labor costs are also dictated by federal and state laws as well as labor market forces, although some types of agricultural labor are also exempted. Many farms are investing in mechanization to avoid the cost and risk of employing labor. Equipment is also expensive, including new technologies. Sharing equipment through rental agreements or hiring customcropping operations could be a way to decrease your investment in equipment. Overall, new technology such as precision agriculture and mechanization can help farms control their input and labor costs, but there are still up-front and ongoing costs to be considered. Some of those up-front costs can be recovered by participating in USDA or other subsidy programs that share some of the cost of improvements, such as renewable energy or other conservation technologies that both reduce some costs of production and have environmental benefits (see "Resources" section). 
Finally, a farm can increase productivity to improve the rate of return. Productivity simply means the rate at which you produce a unit of output (e.g., a bushel) per unit of input, such as land and labor (e.g., acre or person-hour). Increasing productivity means producing more income without increasing your current resources. Some of the ideas already discussed increase productivity, such as switching to higher-value crops on the same land or mechanizing aspects of your operation. Other ways to increase productivity are to add more land, which is a challenge in Oregon because of the high competition for agricultural land and a limited supply. Adding land increases productivity if you can use your current equipment and labor to work the extra land, increasing output overall (but be aware of the rate of return on the new land to be sure it is worth the investment). Oregon is also challenged by the availability of water and presence of wetlands in many areas, which are highly regulated-but getting the ability to irrigate your land or add drainage could also increase the productivity on the land you own. You can also add recreational opportunities such as agritourism or other limited public access for a fee. Again, be aware of regulations and legal and financial risks associated with inviting the public onto your land, but the benefits can outweigh the costs for some operations.

In addition, organizing your business to better handle risk and improving the chances of getting paid for your product-which are discussed in the following section-will benefit the business and your rate of return in the long run.

\section{Value and Incorporate Gen 3 Skills}

The incoming Gen 3 will bring valuable skills and experience to the business, which can foster new business viability options such as the ideas previously discussed. Many family farms require their Gen 3 children to get a college education and experience in a different job before they decide to come back to the farm and begin the process of taking over management duties. Seriousness and experience are invaluable aspects of a competent Gen 3. Nonfamilial Gen 3s are also getting farm management experience, creating a strong crop of young farmers who are eager and dedicated to taking over a successful farm operation. Many Gen 3 graduates studied crops, soils, horticulture, animal science, and other valuable programs. However, to manage a complex farm business, it is imperative that Gen 3s also take courses, or an entire degree program, in agricultural business management, microeconomics, accounting, legal issues, and other business topics as applied to agriculture.

As part of the business succession plan, we recommend that Gen 3 individuals manage a separate business line, bringing in new assets and skills. The succession plan can allow for some independent decision making as well as overlap between the retiring Gen 2 and the incoming Gen

3. The business succession plan can be designed to reach the simultaneous goals of increasing 
farm rate of return and income, strengthening the farm business, and fostering the management skills of the incoming Gen 3.

\section{Increase the Operating Capital}

A business is only viable if it generates excess cash after deducting the cash flow necessary to cover its expenses when they come due. For a farm business, there are high expenses at the beginning of the crop year. During that time, cash flows out to plant and tend the crop and keep the lights on. Payment comes after a crop is harvested and might need to be cleaned, processed, and stored before it can be delivered to the buyer and payment is due. Often, expenses for the new crop season are paid before income from the previous crop has been received. The money that flows out during the crop-year expense-income cycles is operating capital. Many Oregon farms now require millions of dollars of operating capital to bridge the gap between the time when expenses have to be paid and the time when income is received for the next crop.

Farm lenders are key partners in providing operating capital, typically in the form of a line of credit. The number of agricultural lenders is shrinking in Oregon, and operating capital can be hard to come by for some farms. Most operating loans or lines of credit are short-term variable interest loans that take the farm's equipment, products, and accounts as collateral, putting the farm at risk if income does not come in as expected and the loan is unable to be paid (known as secured debt, security interests, and secured transactions, with the lender filing a financing statement / UCC-1; this is different from a loan using land as collateral, which is a mortgage). While lenders that work with farms understand the farm expense-income cycle and can negotiate loan terms, it is prudent for farms to develop their own sources of operating capital, which can also cut down on interest payments and improve the rate of return, reduce risks associated with debt, and improve business viability.

To the extent possible, any net profit from an operating year can be saved by paying down debt with high interest rates or putting the money into investment accounts that offer a reasonable rate of return. A highly liquid account that you can draw on anytime, such as a standard savings account, will earn a much lower interest rate than a money market account that requires a high minimum balance or a certificate of deposit that must stay in the account for a number of years. Excess income can be invested in stocks or bonds to grow over time and can be sold at any time if necessary but with higher risk. Creating pools of liquid assets that can appreciate over time will build an operating capital fund for the future. 


\section{Convert Farm Assets into Retirement Income or Operating Capital}

If you calculate retirement needs of Gen 2, family income for Gen 3, and operating capital to continue as a business and determine that the farm business does not generate enough excess income to meet those needs, then the temptation is to convert some of the ownership interests in the land or other assets into cash through sale, lease, easements, or expanding ownership to more people who contribute capital to keep the farm running. This is a precarious position for a farm and may indicate that the farm business is not viable as operated. Any of these steps to convert farm assets into cash should be done with the utmost care, and cash received should be directed toward investments to sustainably increase the rate of return, because these steps can be irreversible and may lead to the end of the operation. There are several options to consider, with caveats:

Sell land with leaseback and option to repurchase. Land can be sold, generating cash for the business to pay down debt. Reducing the farm's debt load avoids interest payments, and additional cash from the sale of land can be added to the farm's reserves to reduce the need to borrow operating capital. In negotiating the sale, the terms will include the right of the farmer to lease the property back from the new owner on a written farm lease. The terms of the lease should allow the farming operation to reach financial viability-for example, a fixed term (e.g., five years), automatic renewal when the term expires, and the amount and timing of lease payments. The sale and lease agreements should also give the farmer a "right of first refusal" if the new owner decides to sell and an "option to purchase," allowing the farmer to buy back the land if the financial position of the farm allows. Using these kinds of provisions, the transaction can be made reversible, allowing the farmer some ability to pay down the debt or create savings.

Sell equipment with leaseback and option to repurchase. The same contract terms can be applied to the sale of equipment to generate cash to pay debt or build operating capital, with the same caveats. However, equipment will depreciate over time, which can impact the price and desirability of buying the equipment back if significant time passes. It could be a short-term bridge to produce a smaller amount of operating capital if necessary.

Sell an easement. An easement is a voluntary agreement between a landowner and an authorized organization like a land trust or a soil and water conservation district to permanently limit some of the development or use rights on a property. Conservation easements may apply to all or just a portion of the property and need not require public access. Working lands easements are conservation easements that allow farmers and foresters to continue productive farming and forestry operations and keep the land in production forever. Farmers may also enter a conservation easement, which is a promise to not farm a particular parcel that is ecologically sensitive, such as land next to a river, wetlands, or a habitat for critical species. Farmers in Oregon have also developed wetland mitigation banks that restore historical wetlands in exchange for payment from developers that seek permits to destroy wetlands in another area, which is a 
program managed by the state. The easement holder, which is typically a land trust or government agency, is responsible for making sure the easement's terms are followed.

Easements may allow landowners to continue to own and use their land, sell it, and pass it on to the next generation. The farmer may get the payment when they enter into the easement or at regular intervals, depending on the terms of the agreement. For easements "in perpetuity," with no end point, the appraised value of the land is reduced because future owners also will be bound by the easement's terms, although the easement does not necessarily affect sales price where the agricultural value of the land is high. Besides generating capital for the business, an easement can have income and estate tax benefits through deductions if the easement is donated (if applicable) and through reducing the total value of the land. We will discuss taxes in more detail later.

A farmer should exercise caution in entering any easement, whether an access easement with a neighbor or a family member or a conservation easement with a land trust or a government entity. Easements are complex documents and must be drafted carefully with true expertise and an eye toward making sure that the burden and business risk on the land and farming operation are what the farmer is expecting. Entering an easement adds complexity to management, as the easement holder will annually monitor compliance with the easement document. The easement agreement can be fairly detailed, depending on its purpose. Before entering into an easement on farmland, a farmer should seek competent legal, tax, and investment advice, form a relationship with the easement holder, and talk with others who have entered into similar easements.

Sell an equity position. The riskiest option is to sell an equity position in the farming operation, which brings in new owners who will contribute capital. It is crucial to get the help of an attorney and tax accountant with this path because it requires business reorganization and can have serious tax and securities law implications. Including a new partner in the operation can have a big effect on business decision-making going forward. While you can negotiate the rules about how business decisions are made, no amount of documentation can serve as a replacement for two partners who get along, communicate well, and have worked out a way to operate the farm as partners. Unless you are uniquely blessed with that kind of a relationship, you should avoid bringing in new business owners for the purpose of raising capital.

\section{B. Managing Risk for the Health of the Farm Business}

Any business is risky, and farming is a business. Farms' risk-management needs are broad. Farms face risks from natural systems, such as droughts or floods that can devastate a crop and impact contract or loan obligations. Farms manage natural resources and as a result are subject to local, state, and federal environmental laws that may apply. Agricultural businesses typically use machinery and equipment that can be dangerous to workers or other people. Farms face

a range of risks by taking on employees and must follow all employment laws, find and retain 
skilled employees, and set up ways to handle accidents or injuries. Farms often create off-farm impacts-such as smell, noise, dust, or chemicals - that cause neighbors to complain. Many farms have interactions with the public, selling products directly to consumers or inviting the public onto their land. Some farms maintain certifications that increase the value of their product but can be lost through mismanagement or due to natural or human forces that contaminate or damage their crop or infrastructure. Business risk is increasing every day with new markets, new rules and regulations, more development in rural areas, and new interactions with other industries. No one can make business risk go away. But it can be managed using some basic legal and financial tools.

\section{Obtaining Insurance to Manage Risk}

In this section, we will discuss using limited liability business organizations as an umbrella that covers general business risk. But even with an LLC or a corporation, the farm should have adequate insurance to cover liability risks from someone being hurt while on the property, by farm vehicles, by product contamination, by crop loss, or by other insurable risks. As described later, an LLC only limits legal claims to business assets; it doesn't shield the business from all claims. You still need insurance to protect business assets. Adequate liability insurance will cover court costs and some expenses, protecting the business assets.

An insurance policy is a contract. You pay insurance premiums over time, and the insurance pays out in the event that one of the covered risks occurs. The covered risks are either for general categories of items or people such as "inventory" or "employees" or for specific things such as buildings and equipment. There are also limits to the amount of money that can be paid for damages to covered items, and often there are deductibles on claims so that you pay a limited percentage and/or maximum amount of the claim. Claims must also be filed according to the procedures in the policy, such as providing particular information within a certain amount of time after the event. Know what you are getting with your insurance and comply with the terms of the policy. Farm insurance can be expensive because farm activities are risky, so know what you want to cover, shop around, and work with your agent, who may visit your property and give recommendations.

When deciding on insurance coverage, first you should assess the risks on your farm that can be covered. Then choose insurance options for addressing the farm's risks, such as property damage; injuries to visitors, customers, or service providers on your land; worker injuries; crop and livestock damage; and retail and wholesale sales liability.

Property insurance covers damage to structures, equipment, and inventory on your farm from weather events, fire, and theft and can also cover damage from other events such as loss of electricity. Make a list of the property that you want to cover and its replacement value 
when shopping for insurance and make sure to update your policy if you get new items or make improvements to be sure that everything is covered.

Property insurance often comes with liability or casualty insurance, so that if someone comes onto your land and is hurt, the insurance company will handle the defense of any lawsuit and pay damages, up to the limitation amount. If the cost of the injury is greater than the insurance limitations, then the farm is on the hook for the balance. Of course, higher policy limits come with higher premiums, so you have to make decisions about how much insurance you want to carry. If you are doing on-farm events such as agritourism or off-farm activities such as farmers markets or selling products directly to retailers or consumers, your farm liability insurance must have "endorsements" to specifically cover those events or an additional policy that covers product liability.

States require businesses to carry workers' compensation insurance if you have any employees and impose fines for not having the insurance. Rates are based on the riskiness of the work that employees do. And it's just a good idea, because farm work is very physical and insurance is a great risk-management tool. Workers' compensation insurance covers any injury to an employee that arises in the course of employment, so anything from repetitive stress injuries to broken bones that happen on the job is covered. Cover everyone who works for you, from regular employees to interns, to make sure that all potential injuries are accounted for.

Crop and livestock insurance covers losses from natural disasters and is available from local insurance agents who sell and service federally subsidized crop insurance policies for many different types of operations. The USDA Risk Management Agency has resources to review different types of policies.

Insurance is an essential part of farm risk management. While the likelihood of catastrophic events may be small in any particular year, the magnitude of the cost to your business could be devastating. Carrying the right kind and amount of insurance depends on your farm operations and your risk tolerance. Working with an agent, you can create a farm liability insurance package that includes all the necessary components to minimize the impact of catastrophic events.

\section{Managing the Risk of Not Getting Paid}

Farms are also at risk of buyers backing out of contracts or not paying after delivery of products, especially if they sell perishable foods like fruits and vegetables. There are legal tools that you can use to get paid if a buyer backs out or goes bankrupt. These can be difficult rules and laws to navigate. The first step is to get help creating written contracts that protect your interests. They can be used for the types of transactions that you typically engage in and new business lines that you might begin.

Know which laws can be used to your advantage based on what you produce-for example, 
Packers and Stockyards Act (PSA), Perishable Agricultural Commodities Act (PACA), or state laws such as agricultural and landlord's liens and those providing some protection for payment under production contracts. Some of these require basic language in a contract or lease; others require action on the part of the producer if they are not paid. Determine which laws are applicable to the products you sell, create basic contract or lease language, use it consistently, and keep the information on hand; it will save time and effort if you are in a situation where you don't get paid in a timely manner.

\section{Step 2-Ensure the health of the farm business.}

- Determine the income needs of retired Gen 2s, the income needs of Gen 3s and their family, and the farm's cash-flow and investment needs.

- Determine the farm's value by making an inventory and an estimate of the value of each item. Also inventory nonfarm assets for estate planning purposes.

- Evaluate the rate of return to determine if the farm is generating enough income to cover the income needs of Gen 2s and Gen 3s, and the farm's cash-flow and investment needs.

- Make a business plan to "make the pie bigger," if necessary. Your prospective Gen 3s can make a business plan and budget to evaluate a new business line or expansion, for example. Planning to grow the business is a good way to involve Gen 3s and to assess their skills, provide training and experience, and give a sense of ownership over their role.

- Consider options for converting farm assets into cash for operating capital or new farm investment, such as conservation or working lands easements. Remember that some tools can have multiple benefits, such as reducing the market value of the land for estate tax purposes. Other tools come with risks. All must be approached with caution and careful planning.

- Take all appropriate legal steps to manage risks involved in the farm activities that you undertake in your business, from obtaining the right insurance coverage to drafting contracts, filing liens, and invoking other statutory protections when necessary.

- Work with your accountant and other business planning professionals as you make business decisions. 


\section{Chapter 3: Organize the Farm Business Limited Liability Company (LLC)}

When organizing a business, the first thing we talk about is risk. Every business can and should use legal tools to manage risk by limiting the liability of the owners for the acts of the business. Tools include separate business entities, proper and complete insurance coverage, complete and well-structured contracts, lien rights, and other legal protections to manage risk. We have already discussed several of these tools. Now we will focus on organizing separate business entities.

Using well-designed business entities to separate assets from activities with higher potential business risk is key to ensuring the viability of the farm business and passing on the maximum value of the business to the next generation in the succession process. In Legal Tools to Manage Risk

- separate limited liability business entities

- insurance coverage

- contracts

- lien rights or other security protections addition, creating separate legal business entities can streamline the farm succession process by setting up clear rights, responsibilities, and expectations among everyone involved, even the nonfarming family members.

Every operation is unique and faces its own risks, but there are some common tools that help all farms manage those risks and help ensure their long-term business viability-namely, business entities with limitations on liability for their owners called "limited liability business entities." It is important to understand that despite the use of that term, limited liability business entities do not necessarily have limits on liability for their own actions. These business entities are used to separate business assets from personal assets so that business liability threatens only the business assets. Because this isn't a comprehensive solution, maintaining insurance and taking other risk-management steps are still key.

\section{A. Why Form a Business Entity under State Law?}

There are two broad categories of business entities: those in which the owners have liability for business debts and judgments (sole proprietorships and general partnerships) and those that are able to provide the owners with some liability protection if constructed and maintained properly (LLCs, limited partnerships, corporations, and cooperatives). 
Sole proprietorships are the "default" business entities that are formed if you just start doing business, and they have unlimited personal liability for business actions. If the business assets are owned and controlled by one person, it is called a sole proprietorship. This
Around 8o percent of Oregon farms and ranches are currently considered sole proprietorships or partnerships-which implies that many farms have not started their succession planning process. means that all the business assets are held in the owner's personal name-the land, equipment, livestock, and so on-and all debts and contracts are taken out in the owner's name. The business may have an assumed name that is used for marketing, but it does not give further legal protections.

General partnerships are similar to sole proprietorships, but the business assets are owned and controlled by more than one person. Again, all assets and debts are owned in the partners' names, and each contributes personal assets to the partnership. Each partner is seen as an authorized agent of the business, which means that one business partner can sign a contract or loan or otherwise incur liability for the business without consulting the other(s), and all partners are liable on the debt. Business partners share everything-assets and profits along with liabilities and debts. Like a sole proprietorship, there is no separation between a partner's personal assets and the business and its debts and liabilities, resulting in unlimited liability so that if a creditor sues successfully for a business debt, they can also get paid from the farm owners' personal assets, such as bank accounts, vacation homes, or other personal property. While the advantage of sole proprietorships and general partnerships is that they are simple to form-if you own the assets and start doing business, you are governed by their rules-the disadvantage is that they do not protect your personal assets from business risks.

Around 80 percent of Oregon farms and ranches are currently considered sole proprietorships or partnerships-which is a concern because organizing the business as a limited liability entity is a first step to business succession planning, implying that many farms have not yet begun the planning process.

Operating a sole proprietorship complicates the succession process after the death of the owner and is likely to result in substantial loss of business value in the transition, even if a will or trust has been established. Operating a sole proprietorship complicates the succession process after the death of the owner and is likely to result in substantial loss of business value in the transition, even if a will or trust has been established. Transferring the ownership of each of the owner's business assets to a new generation takes time and money and is not always structured in the best interest of the business.

Limited liability business entities separate the business liabilities from your personal assets (unlike sole proprietorships and partnerships). Separating personal assets from business liabilities is the primary reason for creating a limited liability business entity. Transforming your farming operation into a limited liability company (LLC), for example, involves filing articles 
of organization with the Oregon secretary of state, using the appropriate forms, creating an operating agreement, filing the new entity with other regulatory agencies related to such things as taxes and employment, and operating the business according to the rules. The important distinction is that the business is recognized as its own legal "person" in the eyes of the law. It is separated from your personal assets. Unlike a general partnership, owners of the LLC cannot make decisions on behalf of the business or other owners unless they are authorized to do so in the operating agreement. The business entity can own property, enter contracts and loans, sue, and be sued. The business entity stands in the place of the business owners. Therefore, if the business is sued or defaults on a loan, the business and its assets carry the burden of the risk, not the owners.

Of course, the owners put their investment in the business, and that investment is at risk. No entity operates behind a perfect magic legal shield; people can still sue the business for debts and liabilities. But if operated correctly, it limits the owners' liability to the assets that they have invested in the business. When done right, and without the presence of other circumstances leading to an owner's personal liability, it provides some protection for personal assets in lawsuits or other claims. Your business lawyer may advise that you would be better off setting up your farming operation as an LLC because a shield, even if not bulletproof, is better than no shield when you are being sued.

\section{B. Choosing a Business Entity}

Every business operates within the legal rules of the county, state, and federal government. The types of entities available to form a business and their primary characteristics are established by the state. The state also creates and enforces the laws regarding contracts, loans, property, and torts.

In short, you should choose the business entity available in your state that carries the right mix of limits on an owner's personal liability for business debts and judgments, minimizes taxes when moving assets around, maximizes your ability to control the business, and is manageable to administer while facilitating your ability to pass the business on to the next generation. Only a skilled business

Four characteristics to consider when choosing a business entity:

1. Liability of owners for business debts

2. Taxation

3. Owners' rights, such as decision-making and profit-sharing

4. Ease of administration and succession lawyer familiar with you, your business, and your goals and aspirations can advise you on the correct business entity for your purposes. Here we will discuss some of the choices available in Oregon with the hope that this information will 
help you ask questions of your legal, tax, and financial advisors and understand the implication of their recommendations as you make the right choices for your family and business.

Most lawyers will begin by pointing out the need to organize the farming operation as a form of business entity that will separate its actions and other liabilities from the owners' personal assets and the farm's hard assets, like land or livestock. This will provide some protection from liability to its owners. No business organization can provide perfect separation or perfect limitation of liability for the owners. It's a risk management tool, not a risk elimination tool, and there is no perfect solution. Further, improper business formation and lack of careful maintenance can erode even the most basic aspects of separation and liability protection. Everything must be set up and maintained correctly for the owners to enjoy the benefits of business organization.

Key legal advice: separate the farming activity from the ownership of land to protect the value of the land from legal judgments that arise from farm operations.
That said, most business lawyers will begin by advising the farm owners to separate the farming activity from the landowning activity. The simple goal is to place a barrier against liability between the entity with the greatest likelihood of injuring someone and the entity that owns the farm's most valuable asset-land or cattle. Therefore, the typical first step in a business succession plan is to get the farming operation itself-the activities of buying, selling, farming, hiring, and so on-into a separate organization from the farm's hard assets, such as the land, and the owners' personal assets.

Here we will discuss the characteristics of LLCs rather than corporations or other limited liability business entities. We will analyze the LLC in the context of the four main goals for choosing a business entity previously discussed. There are other entities available that offer limited liability, but these vary in their tax requirements and other implications; they are corporations, limited partnerships, and even nonprofit corporations, which your operation could be qualified for if it had a charitable purpose. Corporations, for example, are much less flexible than LLCs and so are rarely used unless there is a high operational risk, such as selling food directly to the public. Currently, most for-profit family farms seem to be choosing the LLC to organize their operations, so we will focus on that in this guide (see table 3 for LLC terminology) 
Table 3. LLC terminology and characteristics

\begin{tabular}{|c|c|}
\hline Name & Farm Name LLC \\
\hline $\begin{array}{l}\text { Owners / } \\
\text { investors }\end{array}$ & Members \\
\hline $\begin{array}{l}\text { Who makes } \\
\text { management } \\
\text { decisions? }\end{array}$ & $\begin{array}{l}\text { Managers or members (depending on whether a manger is hired who is not also a } \\
\text { member) }\end{array}$ \\
\hline $\begin{array}{l}\text { Creation } \\
\text { document }\end{array}$ & Articles of organization filed with secretary of state and $\$ 100$ fee \\
\hline $\begin{array}{l}\text { Governing } \\
\text { document }\end{array}$ & Operating agreement \\
\hline $\begin{array}{l}\text { Owner's } \\
\text { investment }\end{array}$ & Capital contribution \\
\hline $\begin{array}{l}\text { Ownership } \\
\text { share }\end{array}$ & Membership interest defined in terms of a percentage \\
\hline $\begin{array}{l}\text { Payment of } \\
\text { profit to the } \\
\text { members }\end{array}$ & Distribution \\
\hline $\begin{array}{l}\text { Payment of a } \\
\text { salary to a } \\
\text { member }\end{array}$ & Guaranteed payment \\
\hline $\begin{array}{l}\text { Are members } \\
\text { personally } \\
\text { liable for LLC } \\
\text { debts or } \\
\text { judgments? }\end{array}$ & $\begin{array}{l}\text { No. Liability for business debts and judgments are limited to a member's capital } \\
\text { contribution if LLC integrity is maintained. In Oregon, a judgment against an LLC results } \\
\text { in a charging order against LLC distributions. }\end{array}$ \\
\hline $\begin{array}{l}\text { Can a creditor } \\
\text { have a legal } \\
\text { claim on a } \\
\text { member's } \\
\text { personal } \\
\text { assets? }\end{array}$ & $\begin{array}{l}\text { Not usually, but creditors may "pierce" the LLC veil if members comingle personal and } \\
\text { business funds, do not follow legal requirements for the LLC operation, or } \\
\text { undercapitalize the LLC. }\end{array}$ \\
\hline $\begin{array}{l}\text { How many } \\
\text { members can } \\
\text { an LLC have? }\end{array}$ & One or more; can be individuals, other business entities, or trusts \\
\hline
\end{tabular}




\begin{tabular}{|l|l|}
\hline $\begin{array}{l}\text { Are annual } \\
\text { meetings } \\
\text { required? }\end{array}$ & No \\
\hline $\begin{array}{l}\text { Is there } \\
\text { ongoing } \\
\text { reporting to the } \\
\text { state? }\end{array}$ & $\begin{array}{l}\text { Yes, you must appoint and maintain a registered agent who has a physical street address } \\
\text { in Oregon and fill out a renewal form with the basic LLC information (name, registered } \\
\text { agent, member names, etc.) with \$100 fee. Due on the anniversary of formation. }\end{array}$ \\
\hline $\begin{array}{l}\text { How are LLC } \\
\text { profits taxed? }\end{array}$ & $\begin{array}{l}\text { You can elect the pass-through method of taxation: members file and report the LLC's } \\
\text { income on their own separate personal income tax returns based on percentage } \\
\text { membership interests owned. If you do not elect pass-through taxation, the LLC is } \\
\text { double taxed: once on its profits and again for each member. }\end{array}$ \\
\hline
\end{tabular}

\section{Forming an LLC}

The legal formalities of starting an LLC are relatively easy-just fill out and file articles of organization with the Oregon secretary of state, pay a small fee, and capitalize the LLC by moving existing farm assets into the LLC's name. You should also create an operating agreement for the LLC.

The articles of organization can consist of a simple form supplied by the Oregon secretary of state's office. In it, you report the basic information about the LLC, register an agent to be served in the case of a lawsuit and a person and a place to receive official LLC mail, and pay a fee. In 2019, the filing fee for the articles of organization was $\$ 100$. Then you will file a renewal form every year on the anniversary of the LLC formation with the same basic information (updated if necessary) and a \$100 fee.

The operating agreement defines the rights of the LLC members (owners) and managers. While there are default state rules that govern the relationship between LLC members, it is wise to also create your own operating agreement. Writing an operating agreement that considers the unique complexities of your family and farm business takes some care and attention. After thinking about the options, you can use the help of an attorney to craft the right operating agreement for your situation. For example, in a multigenerational LLC, it is important to clarify who has management control, what members without management rights can vote on, and how votes are counted. It is also wise to set the rules for LLC distributions so that there is no confusion down the road. To keep the LLC in the family, there should be buy-sell agreements for all member shares, so that if a member wants to leave the LLC, they must sell their shares within the family or the LLC can buy them out, with a valuation method and payment schedule defined so that a departing member does not drain the LLC of operating cash. Family members can also decide 
in the operating agreement the procedures for dissolving the LLC if they decide to liquidate the business.

While there are no annual meetings or formal recordkeeping requirements as with a corporation, it is wise to have meetings and keep excellent records of decisions to protect the LLC member-managers if other members are unhappy with the business direction at some point in the future. It's also just a good idea to keep track of the decisions that have been made by the business.

Capitalizing the LLC from an existing farm business involves moving farm assets from Gen 2's personal ownership to LLC ownership, which represents their capital contribution to the LLC. In exchange, Gen 2 owns all the membership interests in the LLC (figure 4, step 1). Gen 2 can then gift or sell membership interests to other people, including family members, immediately or over time (figure 4, step 2).

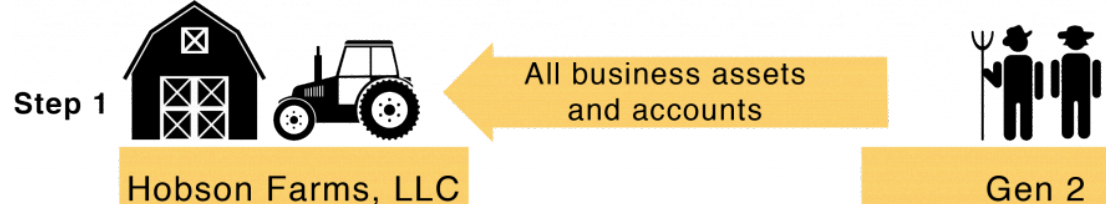

Membership Interests

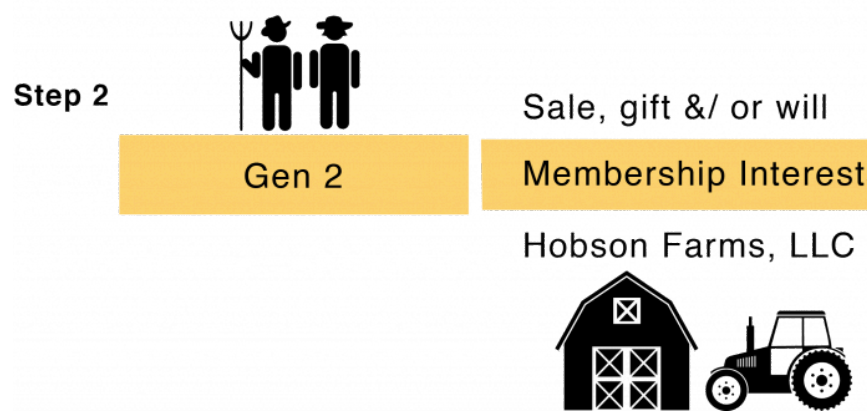

Figure 4. Capitalization and ownership of an LLC 


\section{Operating an LLC}

Operating the business as its own separate legal entity is one of the keys to maintaining the limited liability aspect of an LLC. If someone sues the business, they may "pierce" the limited liability veil of the LLC and go after the owners' personal assets if they can prove that the business was not operated as a legal entity that is separate from the individual members of the LLC (figure 5). This exposes the owners' personal assets to full legal liability for business debts or judgments. The business must have adequate capital to engage in certain functions, such as paying its monthly bills and loans, buying inputs as needed, or paying for other expected expenses. For example, if the business takes on more debt than it can reasonably pay off with expected revenue, the LLC will be considered undercapitalized.

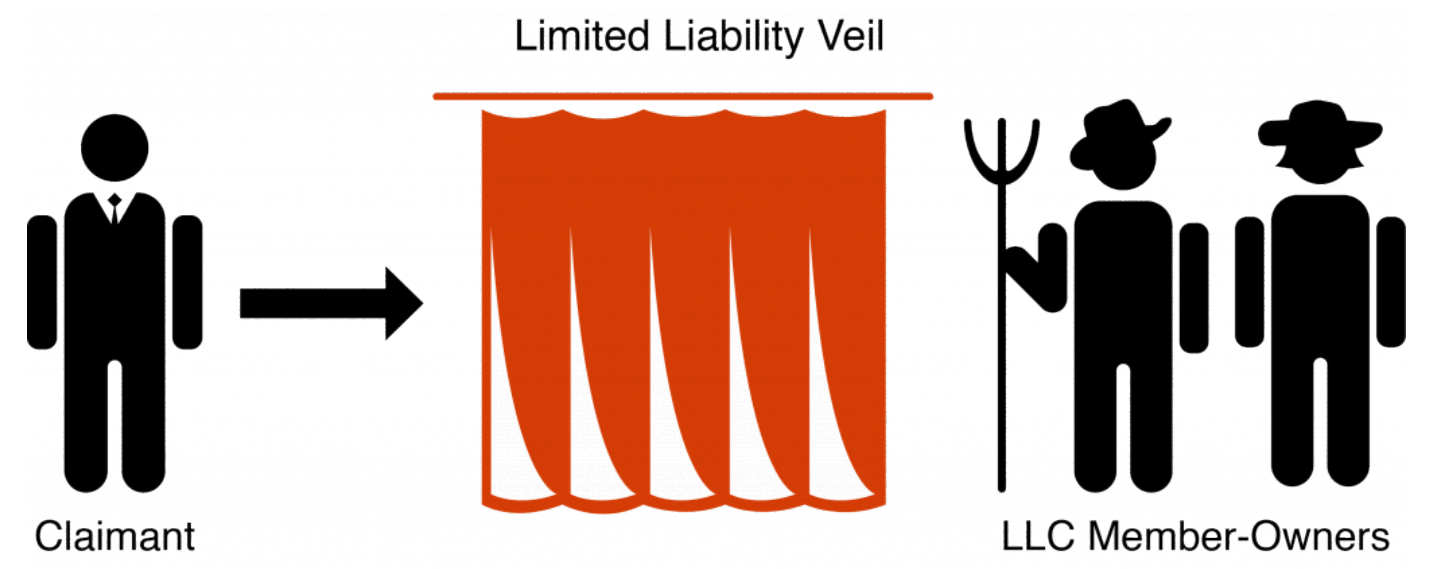

Figure 5. The limited liability veil

In addition, business accounts must be kept separate from personal accounts. Business accounts cannot be used for personal expenses. The business can pay reasonable wages and bonuses to employees, who may also be owners, and profits may be distributed to owners as well. Therefore, it is critical to keep the business assets and accounts separate from personal accounts and maintain proper accounting and business records.

Keeping the business accounts separate from personal accounts can have other benefits, 
especially when there are multiple generations that own the business. Keeping separate business accounts allows managers (and potentially creditors) to evaluate the viability of the business as a business to see if the farm is making enough income to maintain and grow over time. If owners have to keep putting personal assets that come from other sources into the business, such as off-farm work, the business may not be viable for the long term unless changes are made. Keeping business accounts separate also ensures transparency so that all family members with an ownership interests trust that the business is being managed properly. If a family member who is the owner-manager is paying for personal expenses out of business accounts, it will undermine trust and lead to conflict.

Rights of owners. The LLC is a flexible business entity that allows the farm owners to determine their rights in the operating agreement when the LLC is established. One or more people can be members of the LLC. If there is only one member, then there is full ownership and control exercised by one person. If there is more than one member, such as in a multigenerational extended family LLC, many people can be members of the LLC with varying "membership interests," which represent their percentage of ownership in the whole business. The beauty of the LLC is that the business owns all its assets. The people that own the business own a portion of the value of the business, shared with the other members.

If the LLC is member managed, then one of members can be both an LLC member and day-to-day business manager. The other member-owners who are not managers do not have day-to-day management powers, so they cannot interfere with daily management decisions. The operating agreement can give member-owners voting power over big-picture business decisions in accordance with their ownership shares and define the types of decisions that they can vote on. Member-owners are also entitled to a distribution of the LLC's profits based on the percentage of their membership interest in the LLC.

LLC members also have the right to share in the business profits and losses. When the LLC has a profit at the end of the year, it can distribute some or all of that profit to the members, typically in proportion to each member's percentage membership interest.

Taxes. LLCs are eligible for pass-through taxation, another favorable characteristic of LLCs for a family farm business. After talking to your tax attorney and accountant, you may elect to use pass-through taxation, which you indicate on your tax return. By using pass-through taxation, the business's profits and losses calculated at the end of the year are "passed through" to the owners according to their percentage membership interest, and then the owners are taxed on the income on their personal income taxes. The sole proprietorship and general partnership also enjoy passthrough taxation, but as we saw, they do not have limited liability.

The alternative to pass-through taxation is referred to as "double taxation," which is the typical tax treatment for a $\mathrm{C}$ corporation. The corporation itself is taxed on its profits at a corporate tax rate, and then the after-tax profits can be distributed to owners who pay personal income tax on the dividends that they receive from the corporation. For many taxpayers, double taxation is a downside to the corporate business form. 
Ease of administration and succession. LLCs are relatively easy to set up and maintain compared to corporations. While sole proprietorships and general partnerships require no paper work, the small amount that is required for an LLC is more than worth it for the great benefit of limiting personal liability for business debts.

\section{E. LLCs for Succession Planning}

The biggest benefit of an LLC for business succession planning is the ability to separate business ownership from management control (figure 6). Gen 1 and 2 members have worked hard to build up the business, with the support and sacrifice of all their family members. They should be able to continue to reap the financial benefit of the business and share that with their other nonfarming family members. All family members can be LLC members. They are entitled to distributions from the profits of an LLC and can have big-picture decision-making input as defined in the operating agreement. 


\section{LLC Member(s):}

-Voting rights defined in Operating Agreement

-Owns membership interests (\% share of LLC)

- Receives distribution income from LLC profits

-Pays taxes on profits / losses from LLC

•Hires manager

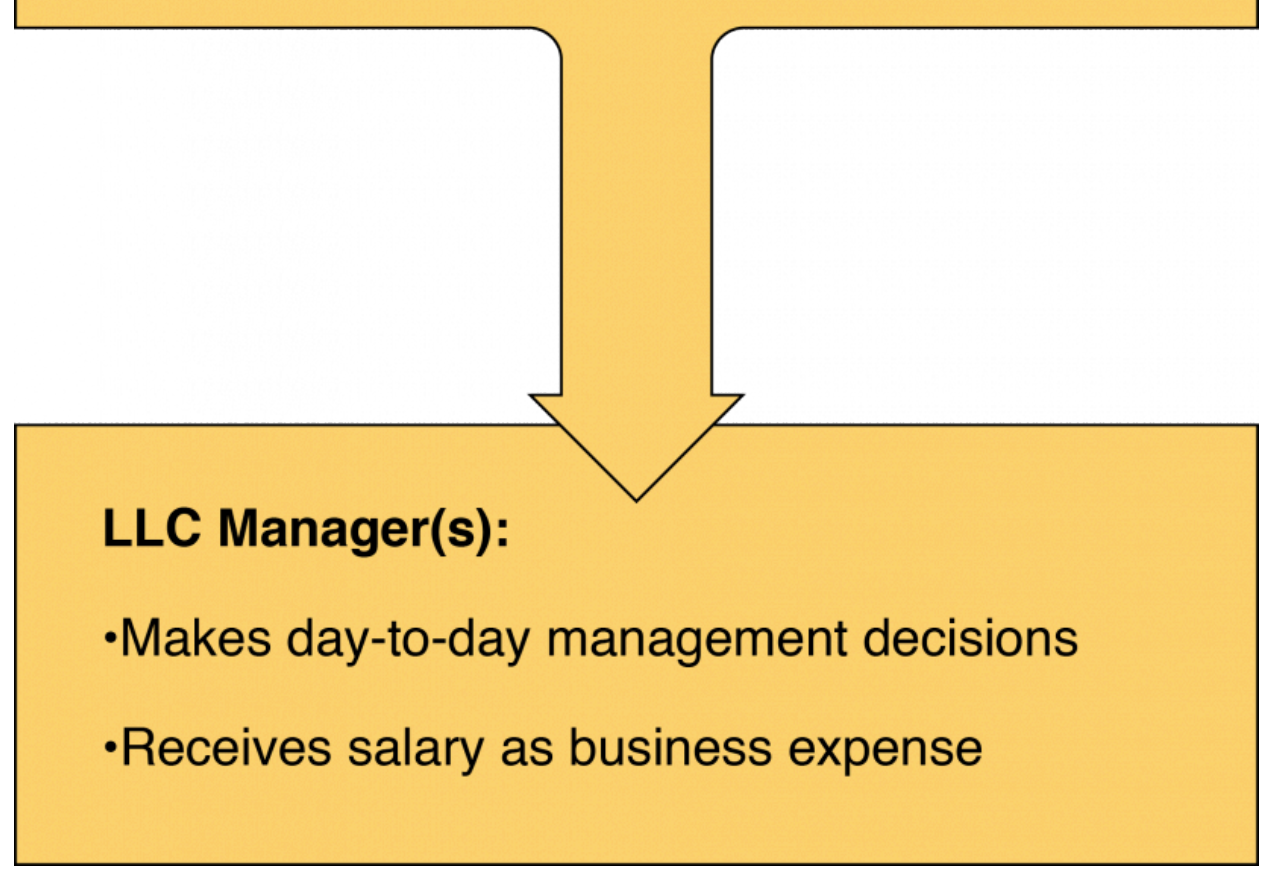

Figure 6. Relationship between member(s) and manager(s)

The Gen 3 operators who are coming back to the farm will want to be able to manage it on a day-to-day basis without interference from other family members who have ownership interests. The LLC operating agreement allows a clear separation of business ownership from management control.

When Gen 3s are ready to start working with the Gen $2 \mathrm{~s}$ on the farm, they may start as a junior manager and may get some membership interests as part of their compensation package. Over time, they may earn or buy more of the membership interests until they move into the full management role with day-to-day decision-making power and own a controlling share of the membership interests. This allows Gen 2 to train Gen 3 as they grow into the position and 
allows Gen 2 to reduce their labor and control over the business until they are ready to retire. It also allows other family members to join in the financial benefits of the business without having management control.

The LLC structure also creates income streams from the profits of the business that can be defined according to the family's needs. An LLC allows retiring Gen 2s, nonfarming family Gen 3s, and the farming Gen 3 s to receive distributions from farm profits. Each owner receives distributions from profit in proportion to their membership interests. Meanwhile, the Gen 2 and Gen 3 farm managers are paid a salary for the labor that they contribute to operating the farm (figure 7). If Gen 2 is cutting back on management duties as they enter retirement, the salary of Gen 2 and Gen 3 managers can be adjusted to reflect their level of effort. If Gen 3 is acquiring ownership interests in the LLC via an option to purchase or as part of his or her compensation package, the distributions from farm profits to Gen 2 and Gen 3 as owners also reflect the percent ownership interest that each has in the LLC.

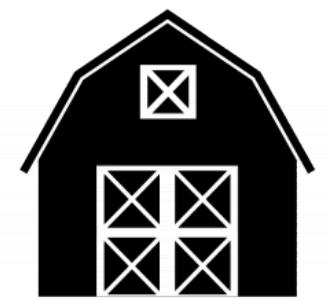

Hobson Farms, LLC

\section{salary,} Distributions

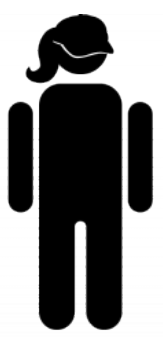

Farm Gen 3

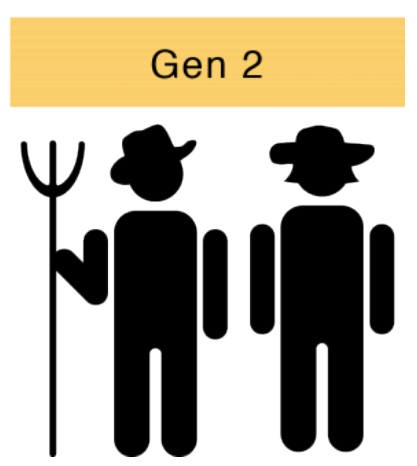

Figure 7. Income streams from LLC to member-managers

Looking ahead to estate planning, putting the farm into an LLC also allows Gen 1 and Gen 2 to pass their membership interests in the LLC to younger generations as gifts while they are still alive to reduce their taxable estate, and they can decide how any membership interests they 
own will be distributed to their surviving family after their death. Holding the business as an LLC simplifies the estate planning process, separating business assets from the personal assets of Gen 1 and 2 and making division with the next generation much easier and more straightforward.

\section{Step 3-Organize the farm business limited liability company (LLC).}

- Get recommendations from other farmers or ranchers or see the "Resources" section to find an attorney who is equipped to work with your farm business and one who you are comfortable with. Conduct several interviews.

- Carefully consider the rights of the LLC owners so that they have clear boundaries between owners' authority and management's authority. Consider which family members should have the right to be an LLC owner. Your attorney can help you write an operating agreement that creates clear rights and responsibilities for everyone involved.

- Remember that organizing the farm as a legal business entity provides immediate riskmanagement benefits and doing it as part of your business succession plans will ease the succession and estate planning process down the road. 


\section{Chapter 4: Organize Your Farm LLCs for Your Business Succession Plan}

Now we move to the next step of getting the farm business organized: setting up organizational structures that serve the business in the present and allow an easy transition to a new generation of owners in the future.

We have already discussed using an LLC to protect personal assets from business liabilities. To further that goal and to provide a flow of retirement income to Gen 2 while Gen 3 takes over operating the business, we will separate the business into two or more LLCs: an operating LLC, a land LLC, and depending on the business, another asset-holding LLC for livestock, vehicles, or other major assets that represent a key business line and source of both capital and liability. Then we connect these different LLCs with other legal agreements, such as leases and contracts, to continue the farm operation with security and stability into the future (see figure 4 in chapter 3 ).

As part of the succession planning process, we are breaking up the farm operationally so that different assets are held by different business entities, which in turn can be owned by different family members if appropriate. When making succession or estate plans, the first thing that most people think of is

Dividing the land parcels increases the chances that the farm will be sold.

Keeping the land together and dividing the income generated from the land keeps the farm together while taking care of family members. to divide their farm by land parcels, giving each to a different child in the next generation, for example. But this strategy increases the chances that the farm will be divided and sold depending on the financial situation of each child that owns a parcel of land. If the goal is to keep the family farm together and grow it into the future, the key is to create and connect different LLCs based on the function that they serve in the business. To reach this goal, we will create a structure that both binds the farm functions together and protects the business and family members from financial harm if something does not go as planned.

A successful succession plan requires that you keep your eye on three important parts of the process: First, everyone must agree on the importance of preserving the farm business and passing it on to the next generation. Your choices about how to craft organizations and agreements between the organizations will be driven by that primary goal.

Second, we must deal with a common fallacy. Most people think that in order to pass a farm to the next generation, it must be organized so that it will last forever and involve all the children and grandchildren, giving them a place to work together and even live together for the foreseeable future. The truth is that never really works. People naturally grow apart mentally and socially as 
each person chooses their own path in the world. Expecting children to raise their own families without the freedom to expand on their own in separate directions is unrealistic.

Third, most farms need to grow in order to be able to provide the income necessary to support both Gen 2 and Gen 3 as the transition occurs. You can't expect to have a successful succession plan by cutting the same size pie into smaller pieces. You are going to need a bigger pie. You will need a business plan that can support multiple families.

Here we will provide an illustration of how this can work. First, we will discuss the motivations and goals for the last-person-standing LLC structure so that you understand why we are making these recommendations. Then we will walk through the details of how a farm business can be structured to meet the goals. In our example, assume that Gen 2 is currently running the farm and thinking of retiring. They have three children. One of the children would like to farm, who we will call Gen 3; however, if there is no Gen 3 in the family who wants to farm, a trusted farm manager can become a nonfamily Gen 3 . The other two children are off pursuing other careers and have no interest in farming. Gen 2 wants to provide for all their children and wants to help a Gen 3 get started in farming so that the farm stays together and continues the legacy that they have built.

\section{A. Motivations and Goals for the Last-Person-Standing LLC Structure}

If the goal is to keep the family farm together and grow it into the future, the key is to create and connect different LLCs based on the function that they serve in the business.
Using separate but connected LLC business entities, we can add structure and firewalls to protect the farm business organization. Additionally, separating the farm functions into different organizations is a strategy for smoothing the business succession process as ownership moves, over time, from Gen 1 to Gen

2 to Gen 3. The farm business can then meet multiple goals: managing multiple business risks, providing retirement income to Gen 1 and 2 while providing household income to Gen 3, keeping nonfarming family in the plan but out of management, moving assets out of Gen 1's and Gen 2's estates to minimize estate taxes, keeping the farm together, and keeping the family together.

Manage multiple business risks. By setting up separate LLCs for organizing the farming operation, land, and other assets, we isolate farm functions with high risk, such as operations, from functions that contain valuable assets, like land. The limited liability veil also protects the owners' personal assets from creditors' claims. For example, if there is a lawsuit because a motorist was injured by a farm vehicle, any judgment against the business is satisfied only from the 
operating LLC's assets. Because the land is held in separate LLCs that are not responsible for the accident, the creditor cannot force the sale of the land to satisfy the judgment. Imagine that each LLC is a containment vessel for risk-related explosions (figure 8).

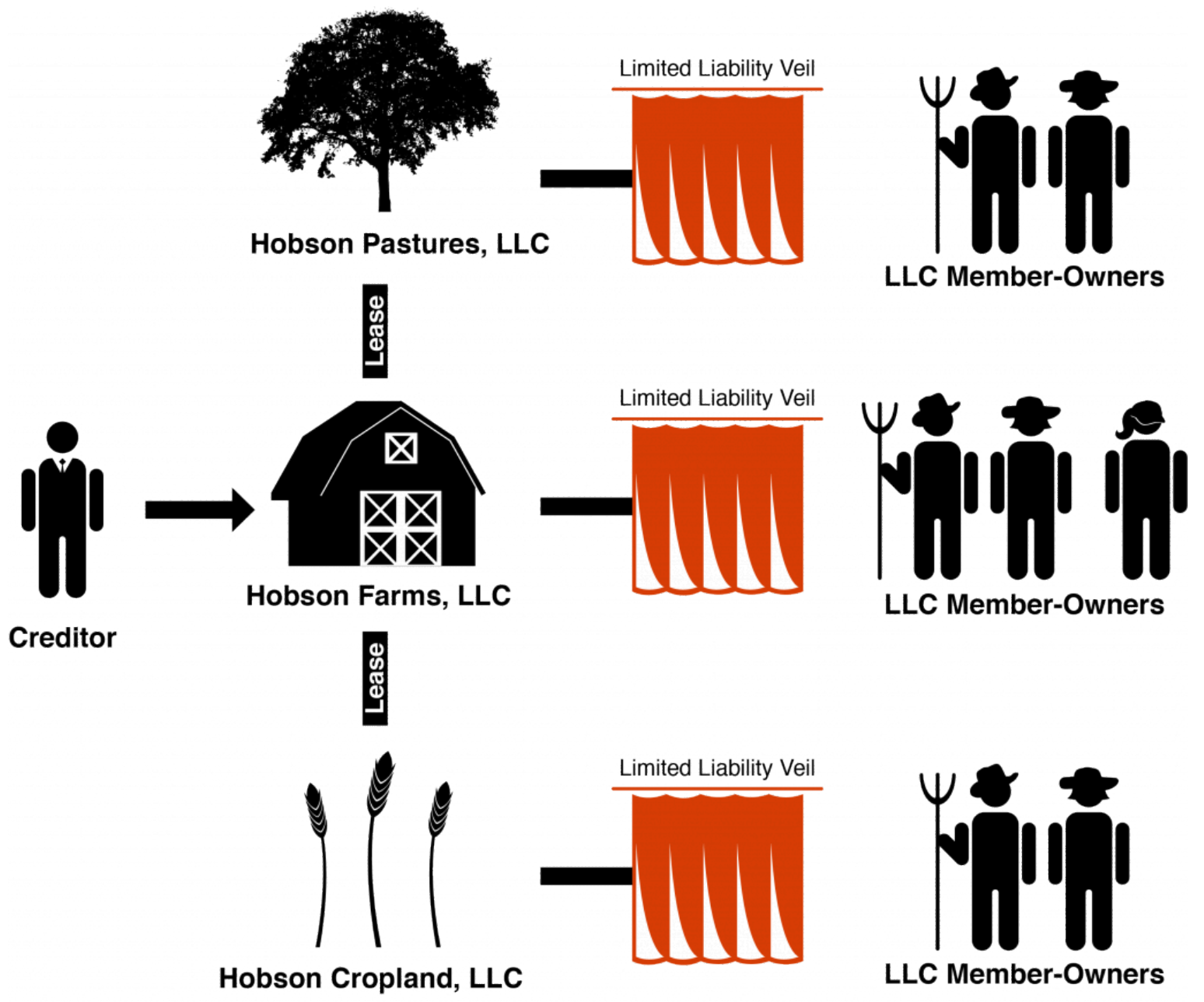

Figure 8. Managing business risk through multiple LLCs

Provide income to family members-retirement income and household income. For example, Gen 1 and Gen 2 can own the land LLC in their retirement, receiving lease payments from the operating LLC. Gen 3 can own and operate the operating LLC, earning a salary and any additional profit from the business. Over time, Gen 3 and other nonfarming family members can obtain ownership interests in the land LLC, receiving rental payments and profit distributions, and ultimately can receive ownership interests as bequests when Gen 1 and Gen 2 die.

Keep nonfarming family in the plan but out of management. This structure allows nonmanagement family members to be passive owners of the assets in the business without giving them management control. Nonfarming family members may still feel a connection to the farm, and Gen 1 or Gen 2 parent or grandparent generations may feel strongly about giving them a 
piece of their farming legacy. However, as we discuss later, giving nonfarming family members management control can lead to discord that harms both the farm business and family dynamics.

Minimize estate taxes. Separating the farm assets into different LLCs owned by different family members reduces the total value of the assets held by Gen 1 and 2, who are also doing their estate plans. Putting some of the value of the business under the ownership of different family members takes it out of Gen 1's or Gen 2's taxable estates. Creating LLCs to hold assets with strong buy-sell agreements and long-term leases also reduces their market value for estate valuation purposes because they cannot immediately be sold to the highest bidder. An accountant and a tax planner are key team members to help with estate tax planning; we discuss in more detail in the next section.

Keep the farm together when a member dies. This structure is far more complex than a simple sole proprietorship, but by creating a thoughtful structure up front, we avoid the complications and loss of value that happens when a farm owner who is operating a sole proprietorship or partnership dies. That situation creates difficulties in terms of estate taxes, property ownership, probate, and other problems that will drain the farm and family of assets and goodwill. The goal of creating a thoughtful and elegant yet more complicated business is to protect farm capital and assets from the costs that come with wrapping up an estate that has significant debt and complex asset ownership, such as a farm.

Keep the family together. It is critical to clearly define appropriate ownership and decision-making roles for both farming and nonfarming family members to avoid confusion and conflict. For example, if the nonfarming family members co-own assets such as the land (rather than the LLC), the potential for disagreement can lead to decisions that are not in the best longterm interest of the farm. The Gen 2 and Gen 3 farming family members may have the right to buy out nonfarming family members, but they may not have the capital or it may require going into deep debt to buy them out to keep the land together. Those situations put tremendous stress on the family and on the business as a whole. By using the LLC structure, all family members can be included in the benefits of the business without giving everyone the right to make management decisions.

This is especially important if a nonfamily Gen 3 comes on as the new farm manager. Family members who identify with the farm can still have a connection to the farm through ownership interests in the LLC but not control of management decisions.

The LLC structure with an operating agreement sets clear expectations and relationships among all family members to ensure a feeling of fairness and equity, even if each family member does not have strictly equal roles in the family farm. 


\section{B. Create the Last-Person-Standing LLC Structure}

The last-person-standing LLC structure is "built to fall apart." It sounds strange, but there is a purpose to this structure. While it can operate successfully indefinitely, it also protects the business and family members from financial harm if the farm runs into financial problems. To create this structure, we break the farm functions into three or more separate LLCs that can be owned by different family members. Then each are bound together using leases and contracts to keep the whole farm operation together yet flexible. Our examples will be "Hobson Farms LLC" and associated asset-holding LLCs, such as "Hobson Pastures LLC" and "Hobson Cropland LLC."

\section{Form an Operating LLC}

First, create an operating entity. This is the business that will plant, raise, harvest, and sell the crops or other products. The operating entity pays all the production expenses, hires the labor, enters contracts, takes out loans, and receives all the income from the farm operation. Any land that it uses will be rented from the landholding entity, which we will describe next.

- File the forms and pay the fee with the secretary of state, and establish the articles of organization for Hobson Farms LLC.

- Transfer business property owned by Gen 2 that is needed to raise the product as if it were a tenant, such as equipment, vehicles, inventory, seed, feed, bank accounts, and so on (but not the land).

Gen 2 will start as the owner/member and manager of Hobson Farms LLC because they owned the farm assets and contributed them to capitalize the newly formed Hobson Farms LLC (figure 9). Gen 3 can become an owner during Gen 2's lifetime through purchase or gift as Gen 2 moves into retirement. The farming Gen 3 should become the only member(s) of Hobson Farms LLC when Gen 2 dies, given appropriate provisions placed in Gen 2's estate plan. 


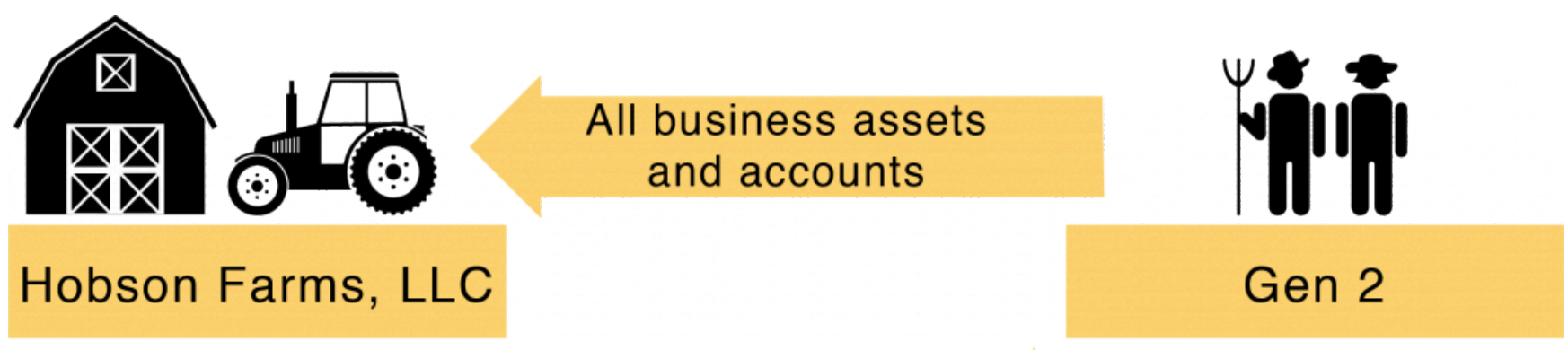

\section{Membership Interests}

Figure 9. Hobson Farms LLC

The operating entity takes all the risk in the business, so it must be a limited liability entity like an LLC, and it must also buy adequate insurance and mitigate its risks. If the business is responsible for damage done to someone else, like an accident between a business truck and a car full of people, having adequate insurance first covers any litigation expenses related to the accident and pays up to the policy monetary limits. If the damages are greater than insurance will cover, a properly maintained LLC structure will protect the farm owners' personal assets from the judgment against the business.

\section{Form Asset-Holding LLCs}

Separate from the operating entity, we will form an LLC to own the land, which we will call "Hobson Cropland LLC" in our example. We will file the forms, pay the fee, and file articles of organization for Hobson Cropland LLC. The purpose of the landholding entity is to acquire land and act as a landlord, renting land to Hobson Farms LLC at fair market value. Having a separate landholding entity provides some protection for the most important asset-the land-from large legal liabilities that can strike the operating entity.

To capitalize Hobson Cropland LLC, Gen 1 and/or Gen 2 will transfer the deed to their property to Hobson Cropland LLC, and they become full owners of Hobson Cropland LLC, which owns the land (figure 10). If there is a mortgage on the land, you will get permission from the bank to transfer ownership to the LLC, which is usually straightforward. Because the landholding LLC is acting as a landlord to the operating LLC, Gen 1 and/or Gen 2 gains a stream of income from the rent payments, taking distributions based on their ownership interests in the landholding LLC. The Farm Gen 3 and the other nonfarming siblings can become owners of Hobson Cropland LLC 
either over time (Gen 2 can gift or sell ownership interests) and/or at the death of Gen 1 or 2 as specified in Gen 1's or Gen 2's estate plan.

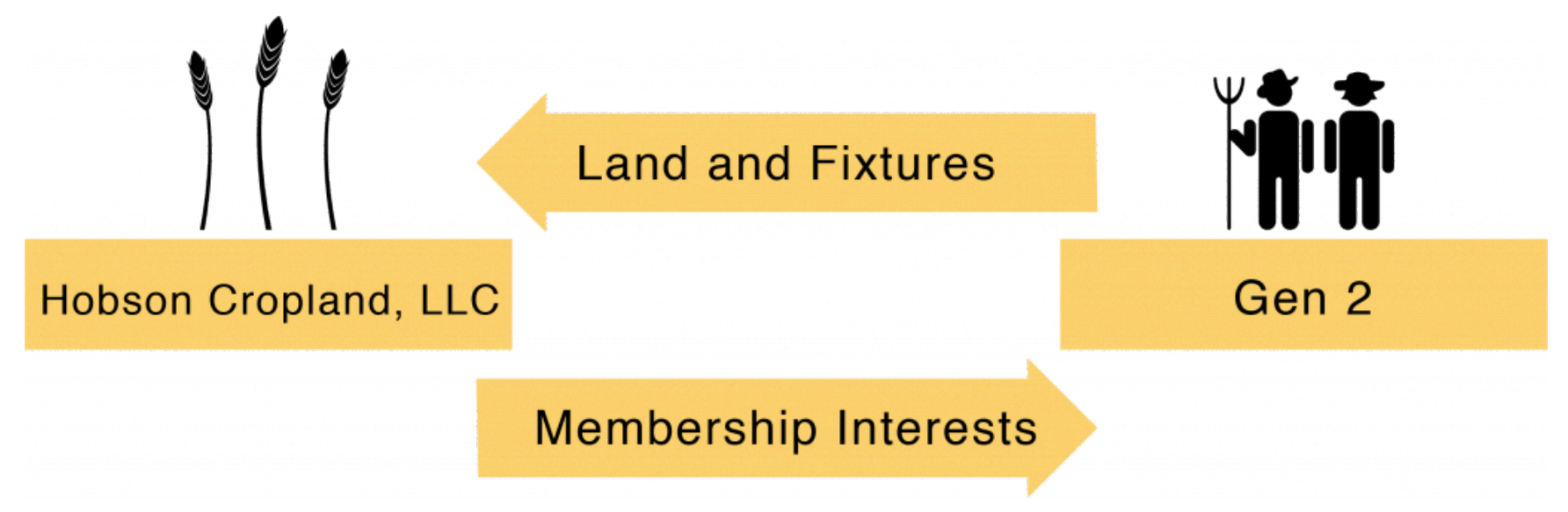

Figure 10. Hobson Cropland LLC

If there are several nonfarming family members that Gen 1 or Gen 2 wants to have an ownership interest in the farm, we can create more than one landholding LLC to fit their estateplanning wishes. For example, if there are several children in the next generation and only one wishes to work on the farm, then we could create two landholding LLCs. One would have the most important piece of the landholdings such as the dairy barns and pastures (or in a different type of operation, the seed-cleaning warehouse, greenhouses, and so on as applicable), which we will call Hobson Pastures LLC in our example (figure 11). This LLC that holds the important farm infrastructure will eventually go to the Farm Gen 3. We then create leases with terms that allow the operating entity, Hobson Farms LLC, to lease the land from Hobson Cropland LLC, Hobson Pastures LLC, or others as applicable. To maintain long-term control of the land for the farming operation, we create terms to allow the Farm Gen 3 to buy out any of the other land LLCs if the nonfarming family members want to sell their membership interests. 


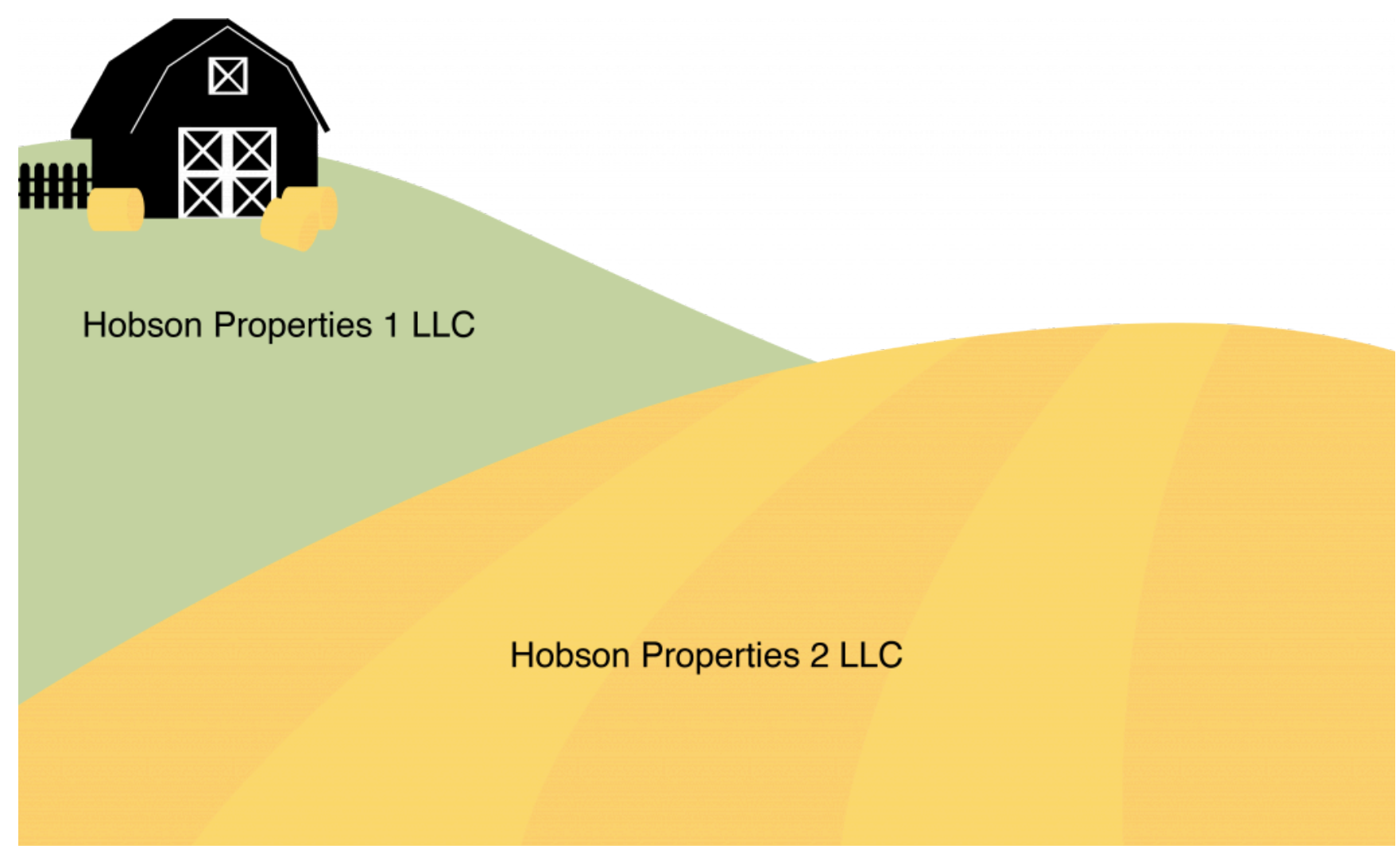

Figure 11. Hobson Pastures LLC

If the family wishes, we can also create separate LLCs with ownership of separate parcels of the farm property for each child that has moved away so that there are as many landholding LLCs as there are children with corresponding gifting plans. Each landholding LLC is subject to the same long-term lease. The operating LLC continues to make all the farming/management decisions and pays rent to the landholding LLCs. Having more landholding LLCs simply adds another item for the accounting and maintenance of more LLCs; it does not change ownership or control in the structure.

Because different family members can have very different financial situations and feelings of connection to the farm, some family members might prefer to be paid for the full value of the land rather than receiving rental payments over time. We can create a financing structure so that the other family members can buy out any family members who want to sell to keep the land in the family. We want to protect the farm against losing land, which we will discuss in more detail in chapter 6.

If the farm operation has a valuable herd of livestock, major equipment, or a major transportation component, we will create other asset-holding LLCs to own those high-value and/ or high-liability assets. Again, this serves the purpose of protecting high-value assets from legal liabilities stemming from another entity's actions. It also separates the operating and land entities 
from many legal liabilities arising from the livestock, equipment, or trucking. In our example, we could create "Hobson Equipment LLC," "Hobson Transportation LLC," or "Hobson Livestock LLC."

Hobson Farms LLC, the operating entity, will also rent the livestock, equipment, or transportation from the other LLCs. Those LLCs can be owned first by Gen 2 to receive rent as a stream of income, gradually selling or gifting the assets in them to Gen 3 so that Gen 3 is eventually the full owner. While Gen 3 may want to dissolve the separate LLCs once they are full owners and combine them all into the operating entity, there is still risk-management value to keeping those assets separate from the operating entity.

Of note, if we create a transportation-focused entity, such as Hobson Transportation LLC, we need to be very careful about what is put in that LLC and how it is used if we want to maintain the agricultural fuel tax exemption and the F plate (for farm vehicles) for the trucks involved. By separating the trucks from Hobson Farms LLC, we have separated the trucks from the farmer. Technically, they are no longer owned and operated by the farm, and that may call the availability of the fuel tax exemption and the availability of the benefits of the F plate into question.

\section{Make the Pie Bigger: Gen 3 Business Entities}

It will be difficult to make the succession a success if all you are doing is cutting the pie into eversmaller slices. There are several ways to make the pie bigger that provide an opportunity for the business to give meaning and experience to Gen 3, deepening their commitment. Options for Gen 3 include developing a new business line, leasing additional land, and buying another farm in the area, if possible.

If it is possible to add another farm or other assets to the business, the new asset should go into a separate LLC owned by Gen 3 (figure 12). If it is a new land acquisition, it would be best if it has a home for Gen 3. Gen 3 will be the owners of the new Hobson Gen 3 Farm LLC, which will rent its land to the Hobson Farms LLC operating entity and get a flow of income back to Gen 3 at fair market value to make the mortgage payments on the land. The lease payments and the mortgage payments for the purchase of the new farm should be as equal as possible so that in the end, the purchase nearly pays for itself. Using fair market value of the land plus interest, insurance, taxes, and maintenance for leases is the best way to determine the lease payments, because that is how the mortgage payments are determined (with maintenance added). The goal is to increase the productivity of the entire farm operation, making the pie bigger and allowing some additional pride of ownership for Gen 3. Then if things do fall apart, Gen 3 has a piece of land that is their own to continue their career in farming or sell (possibly back to Hobson Farms LLC if another manager comes on) to move on to other opportunities. This provides Gen 3 an opportunity to build equity, not just earn a salary. 


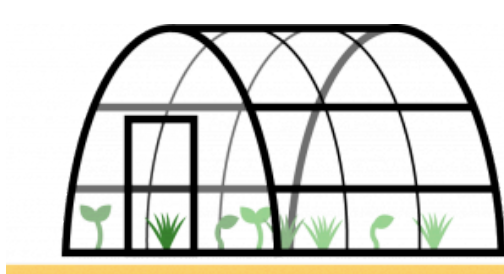

Hobson Gen 3 Farm, LLC

\section{Land and Fixtures}

\section{Membership Interests}

Figure 12. Hobson Gen 3 Farm LLC

Another example has to do with livestock. Assume that Gen 2 has built up a herd over the years. The next-generation farmer will likely want to develop a herd as well. We can put management agreements in place among Hobson Farms LLC, Gen 2's livestock LLC, and Gen 3's livestock LLC so that the two herds can be easily identified at any given point in time. The same kind of lease should be created between Hobson Farms LLC and Gen 3 for livestock as is used for the lease between Hobson Farms LLC and Hobson Cropland LLC. Then each person gets his or her appropriate piece of the economic pie, but the livestock are all raised by and utilized for the benefit of Hobson Farms LLC. Gen 3 has the opportunity to develop his or her own herd and increase farm value, providing pride, ownership, and commitment to the farm business.

If you create a new business line to make the pie bigger, like a new crop or a direct marketing program, you should operate it like it was entirely separate from the farm. That way if a separation occurs, you are set up to make a clean break without many worries. Gen 3 can create a new operating entity, such as Hobson Direct LLC, to undertake those activities and own its associated operating assets. Have written agreements in place detailing the relationship between the two operating entities, and be very clear about which entity owns what. Always run both like they are going to separate at some point-so they can fall apart without questions or acrimony.

\section{Connect the Farm LLCs with Leases and Contracts}

Now that we have separate LLCs for different farm functions, we will connect them to keep the necessary assets available to the operating LLC to earn farm income while providing a flow of that income to the asset-holding LLCs and their owners. All connections are created using standard legal tools such as contracts and leases at fair market value. Each LLC must have its own accounting structure to track the flow of income between the businesses and to the owners 
and managers. This formal structure protects the LLCs and keeps accountability and transparency among family members with different roles, which is important whether or not a nonfamily Gen 3 joins the operation. Family dynamics call for greater transparency and accountability.

Hobson Farms LLC will always operate as a tenant of Hobson Cropland LLC, Hobson Pastures LLC, and Hobson Gen 3 Farm LLC (figure 13). It will not own any land. It can lease additional land owned by other landlords as well. Many business lawyers will suggest farm leases for ten years with an option to renew for additional ten-year periods for as long as Hobson Farms LLC wants to rent the farmland. The rental rate will be adjusted to keep up with full fair market value at each renewal. The farmland leases also provide that Hobson Farms LLC has a right of first refusal to purchase the land before Hobson Cropland LLC or Hobson Pastures LLC can sell it to someone else. They also provide that Hobson Farms LLC has the option to purchase the farmland at any time for the current full fair market value if it ever decides it just wants to own the land.

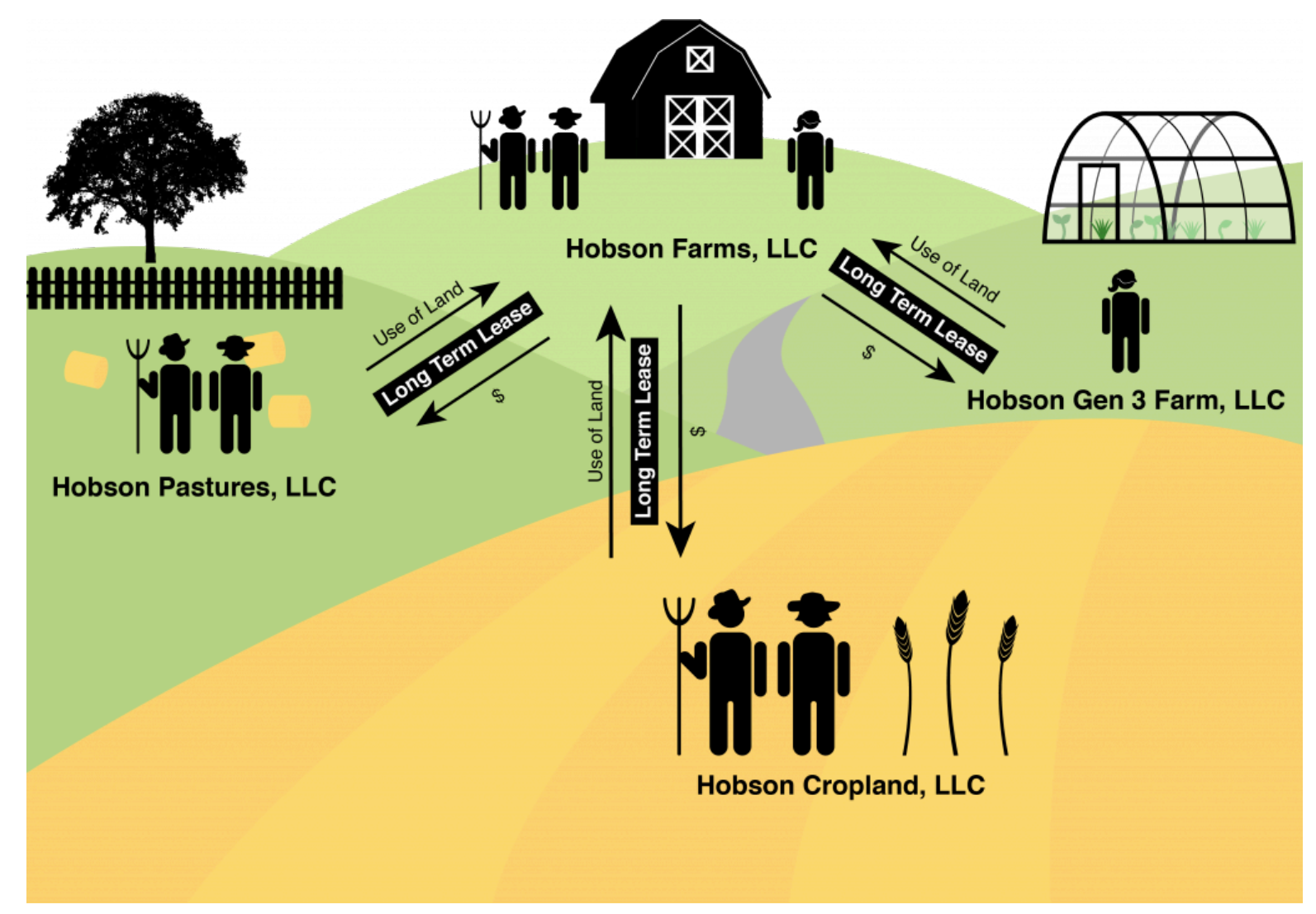

Figure 13. Lease and contract relationships among LLCs

All the leases require the tenant to pay for all three types of land-owning costs, all at fair market value: (1) maintenance, (2) taxes, and (3) insurance. This represents the fair market value of rental land, and if the operating entity is viable, it should be making more money through its operations than the rental value. Long-term farm leases protect the operating entity from losing 
its right to the land so it can feel confident making valuable improvements in infrastructure and improving the value of the land.

Creating and maintaining all of these LLCs provides important risk management, as we have discussed. It also provides a clear stream of income to different family members, depending on their involvement in the farm business (figure 14). Hobson Farms LLC is the active operation, paying salaries to the Farm Gen 3 and Gen 2 as long as they are providing management or labor effort to the business. This is the source of household income for those family members. The Farm Gen 3 and Gen 2 are also LLC members, eligible to receive distributions from farm profits at the end of the year.

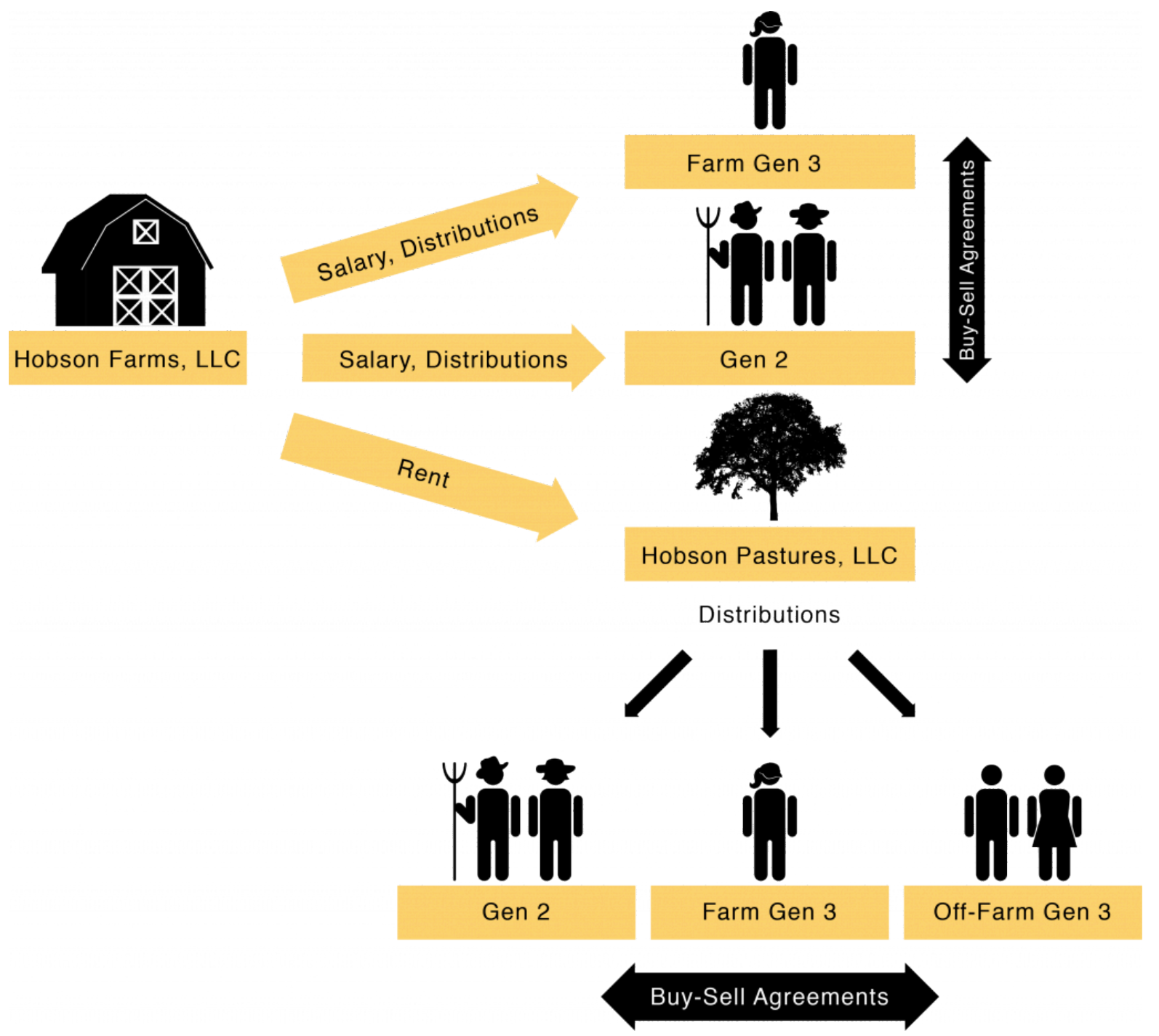

Figure 14. Streams of income to LLC managers and members

Hobson Farms LLC also pays fair market value rent to Hobson Pastures LLC (and any other LLCs). Those rental payments generate profit for Hobson Pastures LLC as a business, which is 
paid out to the LLC members as distributions. All family members who are included as owners as Hobson Pastures LLC receive payments in proportion to their membership interests. By setting up the proper membership interests in each LLC, all family members can be included in the economic benefits of the family farm. We also include buy-sell agreements for each LLC so that the membership interests stay in the family.

\section{Step 4-Organize your farm LLCs for your business succession plan.}

- Learn about last-person-standing LLCs and other business organization options in this publication to save time and money while working with your attorney.

- Review and organize your farm's financials by the function of different farm business activities. Work with your accountant and other professionals to set up the appropriate LLC entities, who will own each entity, and the financial relationships between each entity.

- With your Gen 3s, family, and professional advisors, generate some options for a business succession plan. Considering options allows you to see some benefits and potential pitfalls for different ideas. Review your options with family members and advisors to refine your ideas, and be sure that family and Gen 3 preferences are taken seriously.

- Plan out a business succession timeline. Consider the time it will take to grow the farm business, if necessary; your timeline for retirement; and the training or other skills that your Gen 3 will need before they are ready to take over management.

- Set up milestones for gifting or selling shares in the LLCs to Gen 3 and other nonfarm family members if you want them to begin taking ownership interests before your death.

- Update your plan as circumstances change. Very little ever goes exactly according to plan! Be in communication with your Gen 3 , other family members, and professional advisors as time goes by. Schedule regular check-ins to discuss the plan. 


\section{Chapter 5: Create the Estate Plan}

Now that we have organized the business and set it up for an orderly succession process to let Gen 2 retire and Gen 3 take over management, we can show how Gen 2 can use this structure to create an estate plan that protects their legacy, where the farm business is viable and their family is content with the distribution of their assets after death.

To ensure that the family farm will survive and thrive into the future, it is important that the Gen 3 farm manager gets full control of the operating entity before or after Gen 2's passing. Furthermore, it is likely that there are Gen 3 children who are not interested in farming but still want their fair share of Gen 2's estate. We have already discussed how LLCs can be used to give ownership interests in the business without giving away management control, but some nonfarming Gen 3s might not have an interest in being part of the farm ownership. They may prefer to have other assets-family heirlooms, a vacation home, or simply cash from the estate. While all parents want to treat their children fairly, it is not essential to give each of them exactly the same thing, such as a piece of farmland, or the same value of assets, especially if some of those assets are essential for the business. In order to keep the farm operating and the family together, we tell families that fairness is really about giving each child something meaningful and helpful for their lives. We know that our children can be completely different from one another in every way, and our gifts to them can be different too as long as everyone feels taken care of and understands the reason for the plan that is created. Communication is key to understand expectations, strive to meet expectations, and explain if the plan is not exactly what was expected at first.

Given the business organization and succession plan described earlier, here is how the distribution portion of the will or trust would work: Assume there are three Gen 3 children, and one of the children wants to farm. Also assume that the rest of the children do not want to farm, and they want to live somewhere away from the farm. This example does not address the issues related to a nonfamilial farming successor, sometimes referred to as a nonfamilial Gen 3 . That will be discussed separately. The will or trust with a family Gen 3 would direct that upon the death of the last living Gen 2,

- any remaining membership interests in Hobson Farms LLC will be distributed to the on-farm Gen 3, and

- any remaining membership interests in Hobson Cropland LLC will be distributed in equal shares to all the children and farm and nonfarm Gen 3s.

Keep in mind that following the death of both Mom and Dad, all the leases and any management agreement for land or livestock remain in effect. When the Farm Gen 3 receives all the ownership interests in Hobson Farms LLC, Farm Gen 3 will have full ownership and management control of the operating entity. Gen 3 does all the work and assumes all the risk but 
also reaps the reward. The rest of the children inherit a very valuable asset to be shared equally between them in the form of Hobson Cropland LLC. Hobson Cropland LLC should be designed to operate in a very business-like manner. It should give all the children a way to deal with one another. Done well, everyone should be able to sleep at night without worrying that someone is taking advantage of someone else. It should be structured in a way that allows all the children to get a reasonable rate of return on their inherited investment. It should include provisions allowing a member to withdraw in such a way that it will do no harm to the farming operation while paying the departing member for the fair value of their membership interest (according to the operating agreement). It should include provisions protecting the members from the mishaps and mistakes that can happen in life.

If Mom and Dad are concerned about the fairness of this plan, the trust or will can give family heirlooms, vacation property, personal vehicles, cash, life insurance proceeds, or other investment accounts to certain children. It is important to note that the on-farm Gen 3, who may have spent decades on the farm already before Mom and Dad died, has worked for their shares in the business as well, depending on the plans set up for transferring ownership interests in the LLCs over time. Likewise, the other children have been working in their respective professions in that time and have built up their own livelihoods. Fairness and consideration for each person's circumstances is important for family well-being, but it is also critically important that the farm pass on to the next generation in such a way that it can continue to support the family and contribute to society's need for food and fiber. Talking about the succession plans and being open and honest in sharing Gen 2's goals and wishes with the family can help ease concerns before the grief of the parent's passing is added to the stress of distributing the estate.

If you have a nonfamily Gen 3, they should not be a part of the estate plan. The estate plan is for the family. Your nonfamily Gen 3 should be allowed to buy into an ownership position in Hobson Farms with cash contributions to capital. Closely track the cash contributions so that everyone understands that the nonfamily Gen 3 is not taking any assets that the family Gen 3 feels belong to them. When the last living member of Gen 2 dies, the nonfamily Gen 3 should have the opportunity to buy the rest of the shares in Hobson Farms LLC so that they have full ownership of the operating entity. If the farm is profitable and has a reasonable rate of return, it should be a valuable investment for the nonfamily Gen 3 . If the nonfamily Gen 3 wants to withdraw, they will be paid for their ownership interests in Hobson Farms LLC (which they paid for with cash) with simple interest from the date of the purchase. If the nonfamily Gen 3 was also able to buy land or build a herd or develop other valuable business assets as part of the relationship, they still have full ownership and can go on their way. As we have structured it, the farm could continue to operate with a new hired manager, or it could be sold. The family Gen 3 children would still have ownership interests in the land LLC, so they have a valuable asset that they can sell or rent into the future. Everyone can be taken care of if the arrangement doesn't work out between these particular individuals.

To achieve those goals in estate planning, wills and trusts will be used as the primary tools. 
We will also consider liquidity and other forms of wealth owned by Gen 1 and 2 along with the estate and capital gains taxes that come into play in order to preserve the greatest amount of the value of the estate that will go to the farm and family members.

\section{A. Wills}

When you die, all assets in your name legally go to your heirs. Your heirs will conduct a probate, which is a specialized court proceeding and the only legitimate way to determine who your heirs are and which heirs get what. If you have prepared a legitimate will before you died, that probate will follow its terms. If you have not prepared a legitimate will, then the probate court will create one for you based on a state statute. While the state statute is designed to give your family members your assets after your death in an orderly way (spouse and children, then to more distant family if you have no living spouse or children at the time of your death), it might not be exactly as you or your heirs would wish. Creating a valid will is the best way for everyone to assure that your assets are distributed exactly as you desire.

There are ways to avoid having to go through probate to transfer assets to your heirs. One is to own property with rights of survivorship, where two or more people own the same asset and their ownership is set up so that if one of them dies, the title to the asset goes automatically to the surviving owner. In Oregon, owning land as joint tenants (any two or more people) or as tenants by the entirety (married couples) includes rights of survivorship if the joint ownership is established at the time when you take ownership of the property and both parties have equal interests. Another way to avoid probate is to create a "transfer-on-death" form of ownership. For instance, Oregon now recognizes what is called a transfer-on-death deed, which will allow a person to set up ownership in a parcel of land so that the title transfers to another named person upon the first party's death without giving that person ownership of the land until after the death of the first owner. In addition, most life insurance, annuity policies, and bank and investment accounts give a person the alternative of designating a beneficiary or providing for transfer on death. A better way to try to avoid probate is through the use of a trust.

Even if you have set up ownership of your assets to avoid probate using survivorship rights, transfer on death, or beneficiaries, everyone needs to have at least a basic will just in case

something was missed. Always get guidance from competent professional advisors. For example, there are many potential traps, pitfalls, and dangers involved in setting up joint ownership. It can easily backfire, and what seemed like an easy solution can become a big nightmare. It is essential to get good advice before doing any of the things mentioned here. 


\section{B. Trusts}

A trust can be used as an alternative or supplement to a will. A trust is an agreement between the one who is creating the trust (called the settlor in Oregon) and a trustee. To create the trust, the settlor drafts the trust agreement and transfers assets (the body or res) to the trustee. The trustee holds title to those assets and follows the trust agreement. The trustee holds the title to those assets for the benefit of a third party, called a beneficiary, who you will designate in the trust (figure 15). If some of the trust assets must be spent for the benefit of the beneficiaries, the trustee has the power to spend those assets after ensuring that they meet the conditions in the trust.

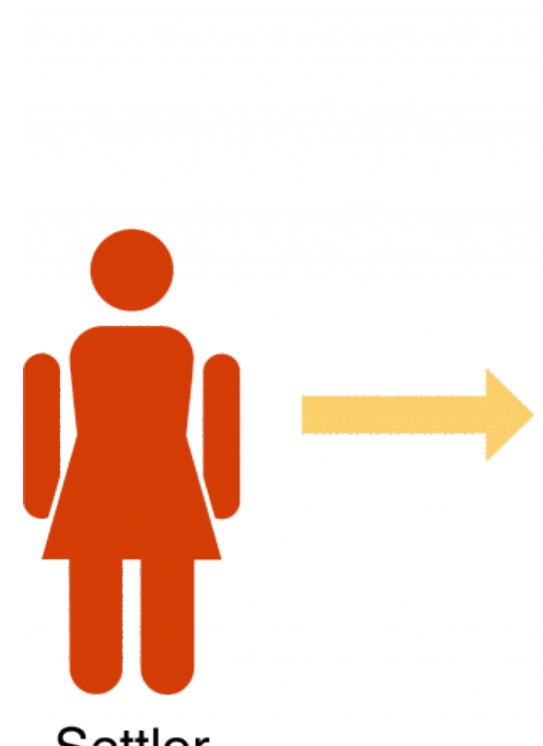

Settlor

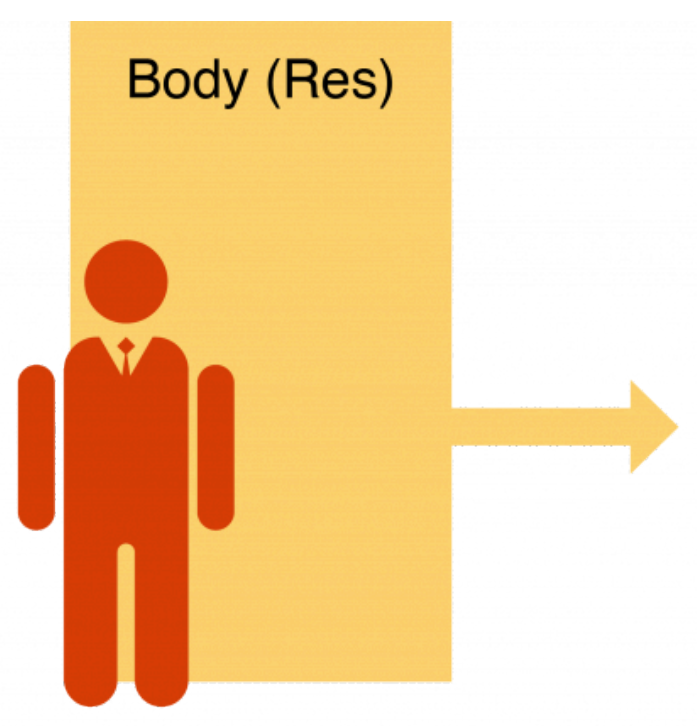

Trustee

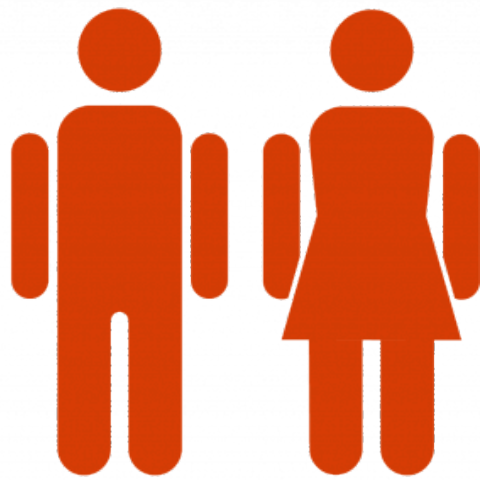

Beneficiaries

Figure 15. Structure of a trust

Under modern law, you can create what is called a "joint revocable trust." That is where a couple creates a trust under which they are the settlors, the trustees, and the beneficiaries all at the same time. They typically convey the title to all their assets to the trust, such that they own nothing in their own individual names. As the beneficiary, they provide that during their lifetimes, the trust assets are there to take care of them. They provide that if they become incapacitated, then a family member or professional will become the successor trustee to manage their assets for their care. Typically, upon the death of the last living spouse, the trustee follows the terms of the trust agreement, pays off any bills, and distributes the remaining assets to the designated beneficiaries, all according to and following the Oregon laws regarding trust administration. Done correctly, they can avoid going through probate, because when they die, there is nothing in their 
individual names. All the assets are in the trust. In the end, a trust can have the same general effect as a will, but it has the benefit of avoiding probate proceedings.

\section{Tax Planning}

While we can't always make taxes go away, we can use some strategies to help families manage them. Remember that we are doing the business succession and estate planning at the same time because some choices can be helpful for both, and we want to make sure that both plans work together. Here we will assume that Gen 2 is a couple, Mom and Dad, who start the process with Dad owning everything in his own name as a sole proprietorship. We discussed the benefits of creating one or more LLCs and moving the business assets into the LLC. For the sake of our example, let's assume that Dad owns the shares in the LLC. While that is a good step and helps a bit, the full value of the business would still be owned by Dad. Now we can show how distributing business ownership and other personal assets to other family members during Dad's life, as we have previously discussed with LLC ownership interests for business succession purposes, can also help to manage estate taxes.

Estate taxes are an enormous hurdle facing a successful transfer of a family farming operation on to the next generation-particularly in Oregon. When a farmer dies without any business succession or estate planning in place, the high value of farm businesses makes them vulnerable to Oregon's estate tax laws. Estate tax liability forces Oregon farmers to make difficult decisions to keep the family farming operation together when a death occurs.

\section{Estate Taxes}

Estate taxes are based on the value of the assets of the deceased person at the time of their death, after all debts of the estate have been paid. If the value of the estate assets is less than the exclusion limit set in the law, then no estate taxes will be due. Therefore, estate tax planning involves understanding the value of the assets owned by someone when they die and finding ways to reduce the value of the estate so that it will be below the exclusion limit. If the value of the estate exceeds the exclusion limit at the time of death, then estate tax will be due.

After a quick review of current federal and Oregon capital gains and estate tax law, we will look at the strategies available to reduce the taxable estate so that it falls below the exclusion limit. This can be a challenge for farm businesses, primarily because the value of farmland is so high-farmers tend to be land rich and cash poor, making high taxes owed on a short timeline 
challenging for the business. However, there are steps to take before death that can be used to minimize or eliminate estate taxes.

Capital gains tax. Capital gains tax is assessed on the difference between the sale price of an asset, like farmland, and its original purchase price (table 4). Long-term capital gains tax rates apply to assets held for more than a year, which would be typical for farm assets. The exact tax rate depends on your tax bracket. For assets held for one year or less, short-term capital gains are taxed as ordinary income. If the farm is sold outright to a new operator, capital gains tax applies and is likely to be higher than taxes due with a succession process and proper estate tax planning, as described later (tables 4-7).

Table 4. Capital gains tax on transfer by sale

\begin{tabular}{|l|r|}
\hline Current Value of Hobson Cropland, LLC & $\$ 1,000,000$ \\
\hline Tax Basis = Gen 2 Original Purchase Price & $\$ 100,000$ \\
\hline Capital Gain on Sale to Gen 3 & $\$ 900,000$ \\
\hline Estimated Federal and Oregon Capital Gains Tax * & $\mathbf{\$ 2 6 5 , 0 0 0}$ \\
\hline *Assuming median Oregon income, asset held over 1 year. \\
\hline
\end{tabular}

Federal estate tax. As of 2019, the federal estate tax does not apply until the net taxable estate rises above $\$ 11.4$ million for individuals and $\$ 22.8$ million for couples. The estate tax exclusion will rise with inflation each year until 2025, when it reverts back to a \$5 million exclusion (adjusted for inflation) if Congress does not pass a law keeping the higher exemptions in place. There is a 40 percent federal tax for estates exceeding the exclusion amount. It is not unusual for an Oregon family farming operation to be valued at \$10 million for estate tax purposes, so most farms should have a tax plan that is flexible and should adjust it based on the current federal estate tax law. It is important to be in touch with a tax planner to keep on top of changes in the exclusion limit.

Oregon estate tax. Oregon's estate tax law is independent of the federal estate tax laws. As of 2019, Oregon's estate tax law only excludes the first \$1 million of the taxable estate, which is a problem for Oregon farms and ranches. The Oregon estate tax rate for the first $\$ 500,000$ over the exemption starts at 10 percent and rises to a maximum of $\$ 1,022,500$ plus 16 percent for an estate valued over $\$ 9.5$ million. Oregon also has the Oregon Natural Resources Credit that may be available if certain criteria are met (see the following section). You should always consult with a tax attorney to keep up with changes and adjust your estate plans accordingly. The Oregon estate tax is often the largest estate tax issue that we need to worry about for Oregon farms. 


\section{Estate Tax Planning Strategies}

Division on the first death. While we are assuming today's conventional arrangement in which Dad owns all the business assets through the LLCs, Mom is still in the picture and can be a joint owner of those assets or hold some in her own name. If the entire estate exceeds Oregon's $\$ 1$ million exclusion or the federal estate tax exemption, we can divide the estate into two so that only half of the total value is subject to estate tax when the first parent dies. This strategy is called division on the first death.

The practical effect of this strategy is to double the estate tax exemption. In Oregon, that means that $\$ 2$ million is exempt from taxes rather than \$1 million. The half that is attributed to Dad is valued as his estate when he dies, with the first $\$ 1$ million excluded. The half that is attributed to Mom is valued as her estate when she dies, with her first $\$ 1$ million excluded. The difficulty is that we have to maintain a firewall between Mom's and Dad's halves to maintain the tax status, which changes and complicates the way that they manage their money. However, it can result in significant tax savings. A tax attorney and accountant are critical if you have a high-value estate in Oregon.

Gifting and federal gift tax. If your asset value is higher than the exemptions, even after considering division on the first death, you can move assets out of your estate by giving them away during your lifetime. Once you transfer ownership of your assets-be it possessions, LLC membership interests, or cash-they are no longer yours and do not count toward your taxable estate. There is one big caveat to gifting: do not give away anything that you do not want to leave the family due to death, divorce, or debt. Once you give something away, you give up all control over it, with a few exceptions if you make a plan. For example, if your LLC interests have buy-sell agreements to keep them in the family, you can give them away with more confidence that the business will stay in the family. However, if you simply give away a piece of land, heirloom, or cash to your child, your child has the freedom to sell it, their creditors can get access to it, or they may lose it in a divorce settlement. Most things of value that you give away are out of your control when you transfer ownership, and you cannot predict what the future holds for the person that you give it to, so choose carefully.

The other caveat is the federal gift tax. In 2019, each person can give away up to $\$ 15,000$ every calendar year to each person that you are giving gifts to, with the amount indexed to inflation. Therefore, Mom and Dad can give a combined total of $\$ 30,000$ to each child or grandchild each calendar year, tax-free. If the gift in a calendar year goes above that amount, you have to file a gift tax return. No tax has to be paid with that return, but it reduces the amount you can pass free of federal estate tax.

Capital gains tax consequences are also possible if a person receives a gift of appreciated and/or appreciating property, like farmland. If a parent gives a child a gift of farmland while they are alive, the child also receives the parent's tax basis for figuring capital gain tax if the property 
is ever sold. Tax basis is what the parent bought the land for, which means that the child will pay capital gains tax on the increase in value between when the land was bought and when it was sold-a large amount in today's markets (table 5).

Table 5. Capital gains tax on transfer of asset by gift to Gen 3, then sale by Gen 3

\begin{tabular}{|l|r|}
\hline Current Value of Hobson Cropland, LLC & $\$ 1,000,000$ \\
\hline Gift to Gen 3 Tax Basis = Gen 2 Original Purchase Price & $\$ 100,000$ \\
\hline Capital Gain on Gen 3 Sale to Third Party & $\$ 900,000$ \\
\hline Estimated Federal and Oregon Capital Gains Tax * & $\mathbf{\$ 2 6 5 , 0 0 0}$ \\
\hline *Assuming median Oregon income, asset held over 1 year. & \\
\hline
\end{tabular}

On the other hand, if the child receives the same land as an inheritance, the child also gets a "step up in basis" to the value of the property on the parent's date of death, a huge benefit given the value of farmland today that likely outweighs the estate tax that would be paid if the parent kept it until death (table 6). Careful calculations and good advice from one's lawyer and accountant are very important to have when you are considering your alternatives here. In addition, forming a landholding LLC would also help to avoid those complications, as interest in the landholding LLC can be given over time and, as discussed next, can benefit from minority discounting.

Table 6. Estate tax on transfer of asset to Gen 3 by inheritance

\begin{tabular}{|l|r|}
\hline Current Value of Hobson Cropland, LLC & $\$ 1,000,000$ \\
\hline "Step up" Tax Basis = Value at time of inheritance & $\$ 1,000,000$ \\
\hline Value of Other Estate Assets & $\$ 600,000$ \\
\hline Total Taxable Estate & $\$ 1,600,000$ \\
\hline Estimated Oregon Estate Tax * & $\mathbf{\$ 6 0 , 2 5 0}$ \\
\hline $\begin{array}{l}\text { *Note that the value of the taxable estate would have to be quite high to } \\
\text { generate an estate tax higher than the capital gains tax resulting from the sale } \\
\text { or gift to Gen } 3 \text { before Gen 2's death, as illustrated in Tables 3 and 4. }\end{array}$ \\
\hline
\end{tabular}

Minority discount. Putting land into a landholding LLC allows us to take advantage of the minority discount when valuing a person's estate at death. We can use the example of Hobson Cropland LLC from chapter 4. Assume that at their death, Mom and Dad own most of Hobson Cropland LLC, having only given away a small portion during their lives. The value of the LLC interests given to the child is the appraised value of the land times the percentage interest the parent owned at the time of death. If the land is worth $\$ 1$ million and the parents own a 75 percent interest in Hobson Cropland LLC, the value attributed to their estate is $\$ 750,000$ just from that 
LLC. That amount will be added to the calculation of the taxable estate to determine whether any estate taxes are owed and how much (see example, table 7).

Table 7. Transfer of majority LLC interests by inheritance

\begin{tabular}{|l|r|}
\hline Current Value of Hobson Cropland, LLC & $\$ 1,000,000$ \\
\hline "Step up" Tax Basis in 75\% of the LLC Value owned by Gen 2 & $\$ 750,000$ \\
\hline Value of Other Estate Assets & $\$ 600,000$ \\
\hline Total Taxable Estate & $\$ 1,350,000$ \\
\hline Estimated Oregon Estate Tax & $\mathbf{\$ 3 5 , 0 0 0}$ \\
\hline
\end{tabular}

However, assume that during their lifetime, the parents were able to give away most of the membership interests in Hobson Cropland LLC, and they only own a 45 percent interest at the time of death. Most appraisers would conclude that the value of a 45 percent interest is not equal to 45 percent of the appraised value of the LLC. Instead, that minority interest can be discounted substantially because a person on the street would not pay full value for it in a closely held family LLC (see example, table 8). There are a lot of trade-offs in using this technique, including that it might prevent the family from using the Oregon Natural Resources Credit described later, so it should only be considered along with advice from your lawyer and accountant. Also, the technique is currently under attack by the IRS, which is promulgating some new rules that would limit or eliminate the technique going forward.

Table 8. Transfer of minority LLC interests by inheritance

\begin{tabular}{|l|r|}
\hline Current Value of Hobson Cropland, LLC & $\$ 1,000,000$ \\
\hline $\begin{array}{l}\text { "Step up" Tax Basis in 45\% of the LLC Value owned by Gen 2 with } \\
\text { 30\% Minority Discount }\end{array}$ & $\$ 315,000$ \\
\hline Value of Other Estate Assets & $\$ 600,000$ \\
\hline Total Taxable Estate & $\$ 915,000$ \\
\hline Estimated Oregon Estate Tax (under \$1 million) & $\mathbf{\$ 0}$ \\
\hline
\end{tabular}

Federal generation-skipping tax. Under the federal estate tax system, the estate tax is imposed on the value of the entire taxable estate regardless of who receives it. A generationskipping tax is imposed on the value of bequests that go to certain transferees who are referred to as "skip persons." Individuals who are two or more generations below the deceased person, such as a grandchild, are a large category of skip persons. The purpose is to make sure that estate taxes are not avoided by continually moving wealth down two generations. If the grandparents gave the money to their children, the children would be taxed on the wealth at their death. If 
the grandchildren get the wealth, then taxes would not be imposed on that wealth until the grandchildren die.

At this time, the exemption from the generation-skipping tax is the same as the exemption from federal estate taxes, which means that grandparents could move a significant amount of money-up to $\$ 22.8$ million for a couple-without incurring the generation-skipping tax. Most Oregon farms will not have to worry about this tax and can leave bequests to grandchildren or in trust to grandchildren without penalty.

Federal special-use valuation. The farmland is the asset with the highest value, so anything to reduce the taxable value of the land is helpful. For federal estate tax purposes, the special-use valuation reduces the value of the estate, allowing some property to be valued for its actual use rather than for its "highest and best use" (as determined by a standard appraisal) for estate tax purposes, such as the value if it were developed into residential or commercial use. However, in Oregon, the development value is essentially the same as the farm value in most circumstances because the state's land-use laws restrict the development of farmland. The farm value is the value of the farm for estate tax purposes in Oregon.

Transferring assets like land into an LLC does not take those assets out of your estate for valuation and calculation of estate taxes. There are several ways to deal with the value of the land in your estate tax planning, such as the following:

- utilizing the Oregon Natural Resources Credit

- gifting some land LLC ownership interests to other family members

- discounting minority interest

- planning to have cash available to pay any estate taxes due so that land does not have to be sold

Conservation easements. One way to generate some cash for the farm business is to sell a conservation easement or working lands easement to a nonprofit land trust or a state or local agency. These transactions also reduce the land's appraised value (although they do not always reduce its actual sales price), because the easement restricts the use of the land in the present and future, even for future owners. The land has a lower market value because any future owner has to abide by the terms of the conservation easement. Of course, the cash value of the easement goes into the business and estate, so depending on the timing of its sale and the death of the land and business owner, that value may still be part of the estate.

Donations to charity can also be deducted from federal estate tax in the same way that charitable donations are deductions from income tax. If a conservation easement is donated instead of sold, then the value is deducted from the taxable estate according to specific IRS rules about the type of easement and value of the land. If the easement is given during life, it qualifies for an income tax deduction that can be carried forward for up to fifteen years for qualifying farmers. If the easement is donated by will or by the heirs when settling the estate, it qualifies 
for the estate tax deduction. When considering conservation easements, it is best to consult with your accountant, tax planner, and attorney about the type, amount, and timing of entering the easement and whether it should be sold or donated.

Oregon Natural Resources Credit. Oregon estates valued at less than \$15 million can use the Oregon Natural Resources Credit (ONRC). It operates as an estate tax credit. After calculating the federal and Oregon estate taxes, you can determine whether you can take the ONRC by identifying the "natural resource assets" in the estate, such as land and livestock. The natural resource property must also be farmed by family before and after death to qualify. You then determine the ratio between the value of the natural resource assets (the numerator) and the adjusted gross estate (the denominator). If the natural resource assets are less than 50 percent of the adjusted gross estate, the credit is not available to that estate. In other words, Gen 2 must have more than 50 percent of their assets as natural resource property in their estate to use the ONRC (figure 16).

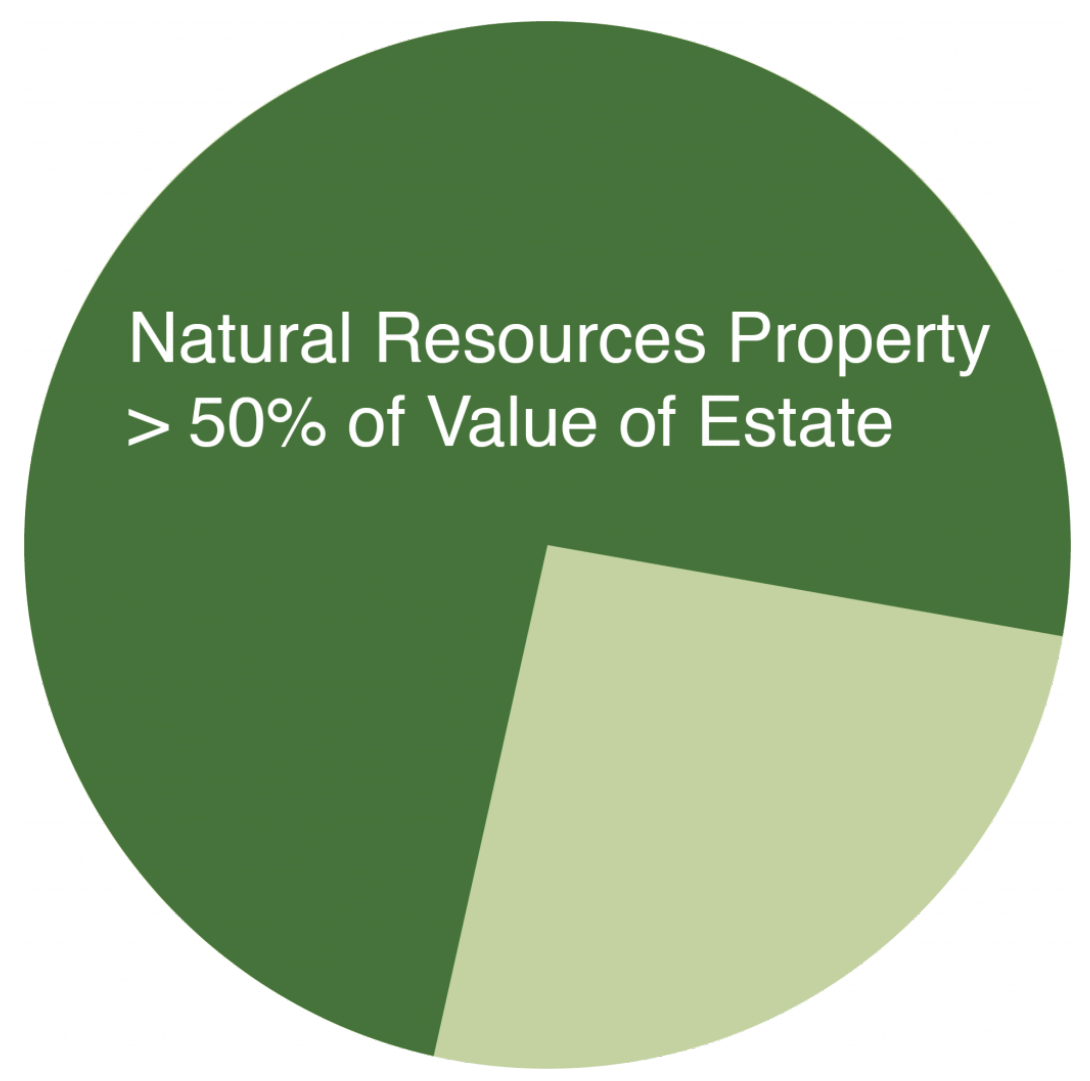

Figure 16. Oregon natural resources property requirement

If the credit is available, then you calculate the credit by multiplying the amount of Oregon estate tax that would be due from the estate by the percentage of the estate that consists of 
natural resource assets represent. If 60 percent of the value of the estate comes from natural resources property, then the estate tax bill is reduced by 60 percent.

Another important consideration here is the effect of a gifting plan on the ONRC. The ONRC is only available if the estate consists mostly of natural resource assets. If you want to be able to take advantage of the ONRC on your death, you don't want to give away so much of Hobson Cropland LLC that the value of your remaining interest in the LLC is less than your assets that are not natural resources. If you want to take advantage of the ONRC, you may want to concentrate on giving away other assets, such as investment accounts or interests in the

If you want to use the Oregon Natural Resources Credit (ONRC) to reduce estate taxes, at least half of your estate's value must come from natural resources assets such as the farmland. If you are gifting ownership of the LLC that owns the land while you are alive, be sure to keep enough of it in your estate so that you can use the ONRC. An accountant and tax attorney can help you with this planning operating entity, Hobson Farms LLC, so that the majority of your taxable estate comes from land or other natural resource property.

\section{Liquidity}

For most farms and ranches, the vast amount of the value of the estate is tied up in the business assets. We need to keep in mind that transferring assets like land into an LLC does not take those assets out of one's estate for purposes of valuing the estate and calculation of estate taxes. Upon setting up and funding an LLC, the value of the land is now in the LLC, but at the same time, the corresponding value of the LLC membership interest is now in the estate to replace the land. Therefore, the value of the estate stays the same both before and after the creation of the LLC (there is a possibility of "discounting" LLC membership interests, but you need advice from an account and tax expert when determining discounts for LLC ownership interests; see chapter 5). As you sell or gift LLC interests to the next generation, you also reduce the value of the taxable estate. While there can be estate tax benefits to organizing the farm as an LLC, we all need to be prepared for the possibility of death while still owning substantial value in the farm business.

Farm business assets cannot be sold off on a whim; they are necessary to keep the business running. If Gen 2 dies without proper planning, first the debts of the farm are paid, then estate taxes may be due, and there may be little to no cash on hand to pay those bills. Some of their children may also appreciate a gift of cash rather than property or ownership interests in the farm. In the estate planning process, we have to build in some liquidity-a way to generate cash-to pay the bills without selling off critical farm assets.

The traditional way of providing liquidity when someone dies is by purchasing life 
insurance on the life of that person so that when that person dies, there is cash available for different purposes. This can be particularly important in the case of farm succession and estate planning because for most farms, the real value is in real estate, which is not liquid. Liquidity makes it easier to pay bills, make a cash distribution to a beneficiary, pay down a mortgage to make continued operation of the farm more achievable, or pay estate taxes without having to sell something.

Life insurance is a contract between the owner of the life insurance and the life insurance company. The life insurance contract specifies the person whose life is being insured. The life insurance contract also specifies a beneficiary. A life insurance contract requires the payment of a premium. And then there is the party that pays the premium. Therefore, a life insurance contract can involve at least four different parties:

1. Insurer: The insurer is the life insurance company.

2. Owner: The owner is the person or entity that gets to decide who the beneficiary of the policy is.

3. Measuring life: The measuring life is the person whose life is being insured. When this person dies, the life insurance contract is triggered, and there is a payout.

4. Beneficiary: The beneficiary is the person or entity that will receive the payout.

The owner does not have to be the party that pays the premium or the party that is the measuring life. The owner, the measuring life, and the beneficiary can all be the same. But if the decedent is the owner, the payout will be included in the decedent's taxable estate. In other words, the decedent's estate will pay estate taxes on the payout. That will be true whether the decedent's estate is the beneficiary or not. This creates a conundrum. Life insurance with Gen 2 as the measuring life is often purchased with Gen 3 as the beneficiary to help pay estate taxes upon the death of Gen 2. But if that policy is owned by Gen 2, then the payout increases the taxable estate at the same time. A work-around has been created, but it is very complicated and full of tax and other traps. It should never be attempted by anyone other than competent legal and tax counsel. It is called an irrevocable life insurance trust, or ILIT. It involves the creation of a very specialized trust that functions as an irrevocable or unchangeable separate entity. Simply put, the ILIT becomes the owner of the life insurance policy with Gen 2 as the measuring life and Gen 3 as the beneficiary with the goal of using the payout to pay estate taxes or other expenses associated with the death of Gen 2 while not including the payout in Gen 2's taxable estate. ILITs are complicated to set up and require annual maintenance. The family must be committed to take on this complication and expense before considering establishing one.

However, one benefit of life insurance is that the beneficiaries, usually a trust, spouse, or child, do not pay income tax or other tax on life insurance proceeds. If the farming Gen 3 is going to receive a high-value stake in the farming operation and other nonfarming Gen 3 children do not want to be part of the business, life insurance proceeds can help provide a distribution of Gen 
2's assets so that all children are taken care of. It can also be used by the heirs to pay for estate costs or any estate taxes that are estimated to be due, which avoids the sale of farmland or other valuable assets to pay for the tax bill.

In conclusion, life insurance can provide needed liquidity, but it should be included in an overall estate plan only after consultation with and under the direction of competent legal and tax counsel with the involvement of a competent insurance advisor.

\section{Step 5-Create the estate plan.}

- Continue to consult with your family members about their wishes when you decide how to create a gift for each of them in your estate plan.

- Consult with your professional advisors about any additional insurance or financial instruments you need to address estate taxes (if they apply) and to give gifts to nonfarm family members.

- Review your plan on a regular schedule, and update it as circumstances change. 


\section{Chapter 6: Putting It All Together}

\section{Business Succession and Estate Planning for the Long Haul}

By working through the business succession and estate planning processes, you have taken steps to preserve the long-term health of your business and to plan for the future of the farm and your family members. Your careful planning preserves the farm and its value into the future. It is important work and is a great gift to your family, to Oregon agriculture, and to society.

After getting into the details of each part of the planning process, it is critical to again step back and see how the plan will work for both the family and the farm business. You will also need to be sure that each part is working together. Regular communication and maintenance of the plans over time with your family and your team of legal and financial experts are essential.

You can also evaluate your plan to see how it will help you withstand some common disruptive life events, such as an unexpected death, divorce, or bankruptcy. Your plan can be designed to help you weather these storms, keeping the farm and family intact. In this chapter, we will share some of the lessons learned from years of working with farm families and observing how their business succession and estate plans have worked-or have fallen apart-so that you can benefit from that experience while you are making your own plans. The goal is to create a structure that shelters your family and farm business from some of life's common storms.

\section{A. Make the Current and Long-Term Farming Decisions, the Succession Plan, and the Estate Distribution Plan Work Together}

The succession and estate planning process can feel complex and daunting because you are planning for your farm and family in the present and for the future. The goal, of course, is to make all pieces of the family farm work together. The problem with making the pieces work together is that farm families typically find themselves working with their family concerns and the business concerns separately. The following set of questions can help you think about how the different parts work together: 
- What is the estate distribution plan?

- What is the succession plan?

- How is the farm organized?

- How are the assets owned?

- What is the investment plan?

- How will the business grow?

- Who makes farming decisions?

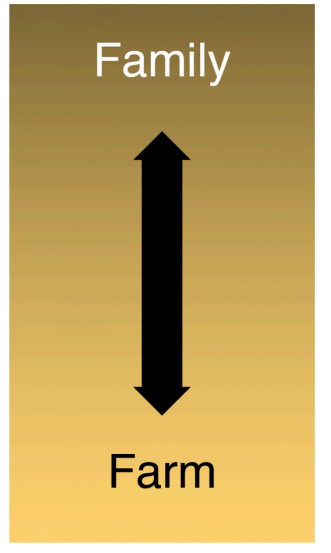

Figure 17. Related family and farm issues

As you can see from the list, the pieces at the top are purely family oriented, while the pieces at the bottom are pure business concerns. The pieces in the middle tend to be a little of each (figure 17).

A good exercise is to stop and ask yourself these seven questions and then analyze the answers. Then ask your family members to do the same and share your results. You can start at the top and work your way down or you can start at the bottom and work your way up. You should be asking yourself, Is everything working together to achieve roughly the same ends? Are there gaps? Are there loose spots? That will help you identify areas that need some work.

Keep in mind that no family farm can claim perfection here. And this is an iterative process. You will keep coming back to your plans and refining them. You may put some estate distribution plans in place and then later buy some additional life insurance that will go to one of your kids, which means that you have to change your plan to account for the new benefit to one child. Finally, the basic rule is that life happens while you are busy making plans. As with anything related to farming, success or failure should be based not on the achievement of specific goals but on the achievement of positive trends. Is the farm business growing as intended? Did estate tax laws change? Are the kids or any other farming successors satisfied with the plan-have you actually sat down and asked each one individually? Are you satisfied with the plan? Or is there something that still is not right, which will get in the way of Thanksgiving dinners now and in the future? 


\section{B. How Getting Organized Can Help the Farm and Family Weather Disruptive Life Events}

The different pieces of the business succession plan, including any LLC operating agreements, must address several realities for the farm to pass to the next generation and survive the ups and downs of life. We outline some here and how to guard against them in the succession and estate planning process.

\section{Death}

No parent expects a child to die before them. No child expects a sibling to die before them. But these things do happen. When a person dies, their assets become part of their estate. They may have a will or trust in place to govern how their assets are distributed upon death. If one of those assets is membership in a family LLC, that membership becomes a part of that person's estate and will be transferred to whomever the will or trust may designate.

Any entity used for succession planning needs to take that reality into consideration and include a way to deal with a membership interest ending up in the hands of a spouse or child of a member in a closely held family business.

If the entity is an LLC, the operating agreement and buy-sell agreements for the LLC should contain provisions to manage a situation like this. This will be a provision indicating that the entity and/or its owners have the right to purchase any ownership interest that might become a part of the deceased member's estate. It should clearly set out how to determine the purchase price and provide for payment over time with interest at the prevailing rate and with a payout period that is long enough to reduce the payment amounts so as not to interfere with the farm's cash flow requirements. It should indicate that during the payout period, the heirs of the estate are not owners and do not have a right to vote on business issues.

\section{Divorce}

The unexpected sometimes happens. A member might become involved in a divorce proceeding. A membership interest in a farm family LLC might be assigned to a former spouse as part of the divorce proceeding. An LLC operating agreement or buy-sell agreement should provide that in the case of an owner's divorce, the entity and/or its owners have the right to purchase that owner's interest on the same terms as are provided for the purchase of a deceased owner's interest from 
his or her estate. If the business structure is established before a child marries, encourage them to get prenuptial agreements in place before they do.

\section{Bankruptcy}

A member might become involved in a bankruptcy proceeding. A membership interest in a farm family LLC might be assigned to a creditor as part of the bankruptcy proceeding. An LLC operating agreement or buy-sell agreement should provide that in the case of an owner's bankruptcy, the entity and/or its owners have the right to purchase that owner's interest on the same terms as are provided for the purchase of a deceased owner's interest from his or her estate.

\section{Withdrawal}

Most Gen 2s wish the next generation of family would all work well together and enjoy the benefits of the farm operation that was put together over time at sometimes great sacrifice. The reality is that the ability to work well together in a common endeavor is rare. Many times, Gen 3 family members get along well when Gen 2 is present, but once that cohesiveness is gone, the Gen 3 group begins to separate into its own family groups, which need some distance to operate well. For that reason, the best farm succession plans contain elements that allow the ownership to coalesce around certain family groups within the third generation, with preference going to the Gen 3 who has chosen to stay and farm.

The LLCs in their operating agreements and buy-sell agreements need to have provisions that allow owners to sell their ownership interests in a manner that recognizes the true value of the interests and allow for payment to the withdrawing owner over time with appropriate interest rates. Like the buyout provisions in the event of death, divorce, and bankruptcy, the buyout provisions in the event of withdrawal should allow the operation to fund the buyout without jeopardizing cash flow to maintain the viability of the farm. Again, the most important thing here is to allow the farm to be passed onto the next generation intact. That's why we build the farm business organization to fall apart in a way that does the least damage to the family members if they decide to part ways. 


\section{Providing Opportunity for a Family Member to Buy Back In}

Seldom considered but important in maintaining the fabric of the relationship in a closely held family operation is the ability of a family member who lost or sold an ownership interest to have an opportunity to buy back in and acquire an ownership status once again.

The operating agreement or the buy-sell agreement of a closely held family LLC should have provisions allowing that family member to buy the lost membership interest from the entity or other owners in a businesslike manner by essentially reimbursing the entity or other owners who funded the buyout of the interests of any heirs, divorced spouses, or bankruptcy creditors in the first place with interest. It must be clear that such a right is personal to that individual only and cannot be exercised by the individual's heirs or assigns who are named in his or her will or contractual relationship.

\section{Risk Management}

The first line of defense in a risk-management program is adequate insurance. Liability insurance is relatively inexpensive and should be maintained at levels sufficient to address the increasing levels of judgments being granted for damage that can be caused by the farming operation, including natural resource damage.

Pay careful attention in all of this with respect to who bears the risk of loss. It depends on the circumstances, but in the scenario outlined earlier, Hobson Farms LLC would shoulder most of the risk of loss. Therefore, Hobson Farms LLC would pay for the insurance and would name the other entities as additional loss payees and indemnify the other entities against any risk of loss.

The second line of defense is entity management. The textbook way to promote risk management through entity management is to separate the farming operation from the land and other major assets. That is done by forming at least two separate entities as we have described, with an operating LLC separate from the landholding or other asset-holding LLCs.

\section{Integrating Gen 3}

The most successful succession plans for agricultural businesses provide Gen 3 with reasonable expectations, a sense of ownership, some certainty, and some sense of security. They also provide

protection for Gen 2's retirement while protecting the core business by paying careful attention to cash flow needs while guarding against disruption.

For example, to take care of both Gen 2 and Gen 3, we often put management agreements 
in place. Hobson Farms LLC can hire the incoming Gen 3 farmer to be the manager as Gen 2 begins to step back and take a less active role in the day-to-day affairs of the farm. We might also want to hire the outgoing Gen 2 to be a manager as a way of providing an income for retirement that operates as a business expense for the operation. It is wise to have clear management roles and expectations for each manager to maintain a healthy working relationship as Gen 2 steps back into retirement. Gen 2 must be aware of the tax and retirement income implications of their continued active management in the business.

An increasing problem with succession plans these days is the lack of a family member who wants to come into the business as Gen 3. The first step in addressing that issue is to find a nonfamily Gen 3 who you trust, who is committed to the long-term success of the farm, and who respects your desires to include your family in the business succession process. When developing a plan that includes a nonfamily Gen 3 , it is important to establish at the outset that a potential nonfamily Gen 3 is not an heir. They could be an employee to start with, then perhaps a manager, and potentially a co-owner, but not an heir. With a nonfamily Gen 3 , it is about building a pure workable business relationship. It is not about inheritance. As discussed in the last-personstanding LLC structure, it is important to establish a separate operation involving the nonfamily Gen 3 with new pieces that can be separated out in the event that things don't work out. The Gen 3 business can be separated from the other family LLCs without disrupting the underlying farming

operation and certainly without disrupting inheritance for the family members who are inheriting Mom and Dad's estate.

With any Gen 3 arrangement, whether Gen 3 is a family member or not, it is critical to be transparent, to manage expectations, and to be clear about ownership interests in the farm businesses so that everyone feels secure and that their expectations are being met in the succession and estate plans.

\section{Lessons Learned}

Getting organized to pass the farm on to the next generation takes careful planning and execution. It is important to remember that the most important thing in all of this is not taxes or equality or ownership; the most important thing is Thanksgiving. These efforts involve families, and you want family members to be able to get together for Thanksgiving when it is all said and done. Equally important is preserving the farm so that the family legacy lives on regardless of who owns and operates it day to day.

To preserve the family, first pay excruciating attention to detail. A common misconception is that because it is family, we don't need to worry so much about all the details. The thought is that things will just work themselves out. Don't be fooled into thinking that. Second, be as businesslike as you can. With families, you want to dot the i's and cross the t's more carefully than you would 
with a stranger. Third, don't think that the members of the family will be able to get along and work together forever through successive generations if you just set it up correctly. No matter what you do to set your business succession plan up, it is generally a very bad idea for cousins to be in business with one another. The LLC organization documents we use provide for the siblings to each buy the other out if there is a death, divorce, or bankruptcy so that over the years, there will be only one family owning the LLCs inherited from Mom and Dad. Then the business succession and estate planning processes begin again on a solid foundation.

The distribution of farm ownership and control can be fair without being equal as long as everyone understands and accepts their role, which is much easier to accomplish if it is done through planning together rather than by decree after Mom and Dad are gone. Proper business succession planning is not a handout; it is a leg up. The associated estate planning should be the same. Everyone in the family has different life goals and trajectories, so they should each get a part of Mom and Dad's estate that is unique to their goals and needs.

To be successful at maintaining the family and the farm, everyone needs their own things and their own space. The farm needs to be set up with last-person-standing LLCs and elements that are built to fall apart into definable pieces that can be separated out without hurting anything or anyone if disaster strikes. Then people can work together knowing that at any time, they can take their piece, go off, and make a name for themselves. Whether they stay together or go their separate ways, the assurance that they have some independent financial stake allows them to get together for Thanksgiving as a family, not as business partners. 


\section{Resources}

- Farm Commons and the Sustainable Agriculture Research and Education (SARE). 2017. "A Farmers' Guide to Business Structures: LLCs, Corporations, Partnerships and More." https://www.sare.org/Learning-Center/Books/Farmers-Guide-to-Business-Structures.

- Oregon Farm Link. https://oregonfarmlink.org.

- Oregon Secretary of State. Business. https://sos.oregon.gov/business/Pages/default.aspx.

- Oregon State University Austin Family Business Program. Ag Advisor Search. https://business.oregonstate.edu/familybusinessonline/ag-advisor-search.

- Oregon State University Extension Service.

- Business Management. https://extension.oregonstate.edu/business-economics/ management.

- Business Marketing. https://extension.oregonstate.edu/business-economics/ marketing.

- Estate and Succession Planning. https://extension.oregonstate.edu/ business-economics/estate-planning.

- Finance, Budgeting and Taxes. https://extension.oregonstate.edu/business-economics/ finance.

- Perdue University Extension. Succession Planning Resources. https://www.cdext.purdue.edu/collaborative-projects/succession-planning/.

- Rogue Farm Corps.

- Changing Hands: A Workshop on Farm Transfer and Access to Land. https://www.roguefarmcorps.org/planning.

- Changing Hands Story Series. https://www.roguefarmcorps.org/changinghands.

- Farm Mentorship Program. https://www.roguefarmcorps.org/host.

- United States Department of Agriculture Risk Management Agency. Crop Insurance. https://www.rma.usda.gov/.

- United States Department of Agriculture Grant, Cost-Share, Easement, and Loan Programs.

- Agricultural Conservation Easement Program and Healthy Forests Reserve Program. https://www.nrcs.usda.gov/wps/portal/nrcs/main/national/programs/easements/.

- Environmental Quality Incentives Program. https://www.nrcs.usda.gov/wps/portal/ nrcs/main/national/programs/financial/eqip/.

- New, Women, and Veteran Farmer Programs. https://newfarmers.usda.gov.

- United States Department of Agriculture Grants and Loans. https://www.usda.gov/topics/ farming/grants-and-loans.

- University of Minnesota Center for Farm Financial Management. Ag Transitions. https://agtransitions.umn.edu/. 


\section{Checklist for Farm Business Succession Planning}

We have set out some basic steps of the business succession planning process, but many of them can be done simultaneously. It will be important to continue to revisit earlier steps, such as engaging with family, as you move through the process.

\section{Step 1-Take care of the family by gathering ideas and expectations.}

- Let everyone know that you are thinking about the long-term operation of the farm after you retire or die.

- Talk to your family about your estate plan. Find out how family members would prefer to be recognized in your estate plan. Start establishing expectations about the business succession and estate plan well before it is drafted.

- Discuss farm succession with family members who express an interest in managing the farm to assess their level of commitment and expectations and involve them in the decisionmaking process.

- If you do not have a Gen 3 successor in the family, seek out Gen 3s that would be a good fit by networking with other farmers, connecting with local or state agricultural education programs such as those at Oregon State University, or connecting with other organizations that manage farm training or young farmer programs.

- If you do not have a Gen 3 successor, set up an internship or limited farm manager position as an introductory period with no long-term commitments. You may need to work with several potential successors before you find the right fit. Use the process to plan and practice turning over management tasks to as well as training an incoming Gen 3.

- Identify professionals that can help you through the process. Start with any professionals that you already work with, ask for referrals if you need to find other experts, and get advice from lenders and other farmers.

- Attend a business succession workshop or seminar and explore further business succession resources.

\section{Step 2-Ensure the health of the farm business.}

- Determine the income needs of retired Gen 2s, the income needs of Gen 3s and their family, and the farm's cash-flow and investment needs.

- Determine the farm's value by making an inventory and an estimate of the value of each item. Also inventory nonfarm assets for estate planning purposes. 
- Evaluate the rate of return to determine if the farm is generating enough income to cover the income needs of Gen 2s and Gen 3s, and the farm's cash-flow and investment needs.

- Make a business plan to "make the pie bigger," if necessary. Your prospective Gen 3s can make a business plan and budget to evaluate a new business line or expansion, for example. Planning to grow the business is a good way to involve Gen 3s and to assess their skills, provide training and experience, and give a sense of ownership over their role.

- Consider options for converting farm assets into cash for operating capital or new farm investment, such as conservation or working lands easements. Remember that some tools can have multiple benefits, such as reducing the market value of the land for estate tax purposes. Other tools come with risks. All must be approached with caution and careful planning.

- Take all appropriate legal steps to manage risks involved in the farm activities that you undertake in your business, from obtaining the right insurance coverage to drafting contracts, filing liens, and invoking other statutory protections when necessary.

- Work with your accountant and other business planning professionals as you make business decisions.

\section{Step 3-Organize the farm business limited liability company (LLC).}

- Get recommendations from other farmers or ranchers or see the "Resources" section to find an attorney who is equipped to work with your farm business and one who you are comfortable with. Conduct several interviews.

- Carefully consider the rights of the LLC owners so that they have clear boundaries between owners' authority and management's authority. Consider which family members should have the right to be an LLC owner. Your attorney can help you write an operating agreement that creates clear rights and responsibilities for everyone involved.

- Remember that organizing the farm as a legal business entity provides immediate riskmanagement benefits and doing it as part of your business succession plans will ease the succession and estate planning process down the road.

\section{Step 4-Organize your farm LLCs for your business succession plan.}

- Learn about last-person-standing LLCs and other business organization options in this publication to save time and money while working with your attorney.

- Review and organize your farm's financials by the function of different farm business activities. Work with your accountant and other professionals to set up the appropriate LLC entities, who will own each entity, and the financial relationships between each entity.

- With your Gen 3s, family, and professional advisors, generate some options for a business succession plan. Considering options allows you to see some benefits and potential pitfalls 
for different ideas. Review your options with family members and advisors to refine your ideas, and be sure that family and Gen 3 preferences are taken seriously.

- Plan out a business succession timeline. Consider the time it will take to grow the farm business, if necessary; your timeline for retirement; and the training or other skills that your Gen 3 will need before they are ready to take over management.

- Set up milestones for gifting or selling shares in the LLCs to Gen 3 and other nonfarm family members if you want them to begin taking ownership interests before your death.

- Update your plan as circumstances change. Very little ever goes exactly according to plan! Be in communication with your Gen 3, other family members, and professional advisors as time goes by. Schedule regular check-ins to discuss the plan.

\section{Step 5-Create the estate plan.}

- Continue to consult with your family members about their wishes when you decide how to create a gift for each of them in your estate plan.

- Consult with your professional advisors about any additional insurance or financial instruments you need to address estate taxes (if they apply) and to give gifts to nonfarm family members.

- Review your plan on a regular schedule, and update it as circumstances change. 



\section{Glossary}

\section{Accountant / Certified Public Accountant (CPA)}

A professional who is trained in the recording and reporting of financial transactions, generating financial statements, and giving recommendations about financial decisions. A $\mathrm{CPA}$ is an accountant who has satisfied the requirements necessary to become a certified public accountant.

\section{Administration of the succession or estate plan}

Ensuring that the actions needed for the maintenance and execution of the succession or estate plan are accomplished. Administration may include keeping appropriate financial or business records, transferring ownership interests as agreed upon, and having regular meetings to update and execute the plan as needed.

\section{Agent}

One who is authorized to act on behalf of another (the principal). For example, in a general partnership, all partners are authorized as agents to make business decisions, enter contracts, and the like on behalf of the business, which binds all other partners.

\section{Appraisal}

The determination of what constitutes a fair market price for an asset, typically calculated by professionals in the field based on the sale price of similar property or income-generating potential of the property.

\section{Articles of organization}

Document filed with the secretary of state when forming an LLC to legally register the business entity with the state. Includes basic information about the LLC: company name, duration, principal office street address, registered agent to receive legal notices, management (member managed or manager managed), name of organizer(s), owner(s), manager(s).

\section{Assessed value}

The value that a taxing authority gives to property to which the tax rate is applied. 


\section{Assumed business name (d/b/a)}

The name under which a business operates or is commonly known; "doing business as" (d/b/ a).

\section{Attorney}

A professional who is authorized to practice law in the state.

\section{Bequest}

Giving property by will; the property that is given via a will.

\section{Business assets}

Items or property of value owned by the business for a business purpose.

\section{Business balance sheet}

A financial statement that lists the assets, debts, and owners' investment as of a specified date.

\section{Business entity or organization}

An entity recognized by the law to have legal rights and responsibilities, also known as a "legal person" that can own assets, enter contracts, sue, be sued, etc. A business entity is created by one or more natural persons to carry on a business that defines the owners, the relationship between owners and managers, tax status, and the relationship to others who have dealings with the business. If the business entity has the characteristic of limited liability, the entity must be created by registration with the state, and judgments or debts incurred by the business can only be recovered from business assets-for example, sole proprietorship, general partnership, LLC, C corporation, S corporation, B corporation.

\section{Business succession}

The transfer of ownership and/or control to new people who have ownership interests and/ or management control in the business.

\section{Business viability}

The ability of a business to pay its debts as they come due and continually make a profit year after year.

\section{Buy-sell agreements}

A legally binding contract that stipulates how a business owner's interest may be bought and 70 | Glossary 
sold if that owner dies or leaves the business. Typically, the buy-sell agreement requires the ownership interests to be sold to the remaining business owners or the business must buy back the interests.

\section{Capital gains/losses}

Capital gain is the increase in the value of a capital asset (investment or real estate) that gives it a higher value than the purchase price. A capital loss is the decrease in value compared to the purchase price. The gain/loss is not realized until the asset is sold. A capital gain/loss may be short term (one year or less) or long term (more than one year) and must be claimed on income taxes.

\section{Capitalize/capital contribution}

Giving the LLC ownership over assets (property, money, accounts) in order to carry out the business purpose. The owners of the LLC make a capital contribution when they put business assets that they own into the LLC's name, and in return, the owners get membership interests in the LLC.

\section{Closely held business}

A business entity with a limited number of owners, typically family members in farm businesses. Rules about buying and selling ownership interests ensure that the business cannot be owned by anyone outside of the family (see buy-sell agreements).

\section{Comparable market analysis}

Estimate of fair market value of property through examination of recent sales prices or rental values of similar properties.

\section{Contract}

An agreement between two or more parties creating obligations that can be enforced through the judicial system.

\section{Corporation (C corporation, $\mathrm{S}$ corporation, B corporation)}

A type of business entity that is established according to the laws of the state and is taxed under the Internal Revenue Code according to the type of corporation that is established. Corporations have limited liability, have ownership that is separated from management, issue stock/shares, exist in perpetuity, and operate as a "legal person" (i.e., can own assets, enter contract, sue and be sued, etc.). 


\section{Cost of production / cost of goods sold}

All direct costs incurred in order to produce the products that you sell, such as equipment, seed, irrigation, chemicals, labor, and so on.

\section{Deductible}

In an insurance contract, the amount of money you pay in a claim. The insurance pays any remaining losses after the deductible has been met.

\section{Distributions}

The profits generated by the LLC that are designated for owner-members based on their percentage ownership interest in the LLC. The LLC may choose to retain profits rather than pay them out to owners, but the amount of distributions is attributed to the owners and is reported on owner-member tax returns.

\section{Double taxation}

Tax treatment of a C corporation, which pays taxes on corporate profits based on the corporate tax rate, and then the remaining profits distributed to owners are taxed as dividends on owners' personal tax returns.

\section{Easement}

An interest in land owned by another person, consisting of a right to use or control the land for a specific limited purpose. For example, in a conservation easement, the easement holder (land trust or government) has a right to forbid certain practices on the land while the landowner can still use the land for other purposes.

\section{equitably}

here is another term

\section{Equity position}

An investment made in a business by a third party in exchange for some ownership interest. Giving an equity position includes the third party in ownership of the business, which might not be in the best interest of the business, succession, or estate plan.

\section{Estate planning}

The preparation for the distribution and management of a person's estate at death through the use of wills, trusts, insurance policies, and other arrangements. 


\section{Estate tax}

A tax levied on the net value of the estate of a deceased person before distribution to the heirs.

\section{Fair market basis or value}

The amount for which property would be sold in a voluntary transaction between a buyer and seller, neither of whom is under any obligation to buy or sell (arms-length transaction). Various factors can have an effect on the fair market value of real estate, including the uses to which the property has been adapted and the demand for similar property.

\section{Family successor}

A family member who plans to take over farm management as the principal operator when the current generation retires or dies.

\section{Farm or farmland}

Operation or land that is engaged in producing agricultural products for sale. Includes crop production, seed production, nursery production, ranching or other animal husbandry, apiculture, aquaculture, and so on.

\section{Farm successor}

Person who plans to take over farm management as the principal farm operator when the current generation retires or dies. The succession could be a family member (family successor) or from outside the family (nonfamily successor).

\section{Financial planner}

A qualified investment professional who helps individuals and businesses meet their longterm financial objectives by analyzing their goals, risk tolerance, stage of life, and so on. They assist with investment strategies, retirement planning, tax planning, risk management, and/ or estate planning.

\section{General partnership}

A business entity in which two or more people operate a business for profit and agree to share all profits and losses and financial and legal liabilities. Partners are all agents for the business and can bind the business to contracts, loans, or legal judgments without the consent of the other partners. A general partnership does not have limited liability, so personal assets of all the partners can be claimed to satisfy judgments or debts against the business. 


\section{Generation (Gen) 1}

The "grandparent" generation in the family who managed the farm and may still own land or assets. Typically retired from daily farm management (though not always).

\section{Generation (Gen) 2}

The "parent" generation that is at or nearing retirement age and is typically the active farm manager.

\section{Generation (Gen) 3}

The "child" generation that is in early adulthood and beginning careers either on or off the farm.

\section{Gift/gifting program}

To transfer ownership of an asset without a fair market exchange. LLC membership interests can be transferred (gifted) to other family members during life for estate tax planning purposes.

\section{Heir}

A person who is entitled to receive a deceased person's property due to family relationships under the state's laws of intestacy, which govern the distribution of an estate when there is no will. In common use, can also refer to a person who inherits under a will.

\section{In perpetuity}

Forever; with no defined end time.

\section{Insurance policy}

A contract between an insurance company and an insured person or business. The insured person or business pays premiums for coverage, and the insurance company pays any losses that are covered in the policy. It describes the specific risks covered, exclusions, duration of coverage, amount of premium, and deductibles, if any.

\section{Interest(s)}

An ownership stake in an LLC. Refers generally to ownership stakes and specifically to the percentage of profits that is attributed to individual owners that determine voting rights, distributions of profits, and other aspects set out in the operating agreement. 


\section{Lease}

A contract in which an owner of real property gives another person or business the right to possess and use the property in exchange for rent payments. A written lease should contain all conditions for use the land and the rights and responsibilities of tenants.

\section{Lien}

A legal right or interest defined by state law that gives a creditor an interest in a debtor's property until the debtor pays the debt.

\section{Limited liability}

A characteristic of business entities that are defined and registered by state law that limits any debt or judgment against the business to be paid only from business assets, not the personal assets of the business owners.

\section{Limited liability business entities}

This is a glossary

\section{Limited liability company (LLC)}

A form of business entity that is defined and registered by state law that confers limited liability to its owners, can be structured to separate ownership from management control, and can elect pass-through taxation. Created by filing articles of organization and may be governed by an operating agreement.

\section{Membership interests}

Ownership stake in an LLC that represents a percent interest in the business and corresponds to voting rights and distributions.

\section{Net profit / net income}

The amount of total revenues from the business that exceed total expenses. Net profits / net income can be used to pay off debt and invest in new assets or business activities, saved as operating capital, or distributed to owners.

\section{Nonfamily successor}

A person who is not a member of the current operator's family who plans to take over farm management as the principal operator when the current generation retires or dies. 


\section{Operating agreement}

Describes the rights and responsibilities of LLC members, setting out the terms and conditions that all members agree to, such as voting rights; manager duties, qualification, election, and removal; distribution of profits; procedures for adding new members and who qualifies; meetings; buy-sell agreements; dissolution of the LLC if desired; mediation or arbitration of conflicts; and so on. If the LLC does not create an operating agreement, existing state laws will govern any dispute among members or managers.

\section{Operating capital}

The business's cash on hand used for daily operations and to pay bills or debts as they come due.

\section{Operating loan}

A loan given to a farm to meet cash-flow needs between when expenses are due and when payment is expected from the sale of farm products.

\section{Operator (farm)}

The farm operator is a person who makes day-to-day management decisions. The operator could be an owner, a hired manager, or a tenant. There can be more than one operator per farm; for example, if the retiring and successor generations are both making day-to-day management decisions, they may both be operators. If land is rented, the tenant or renter is the operator.

\section{Option to purchase}

A contract provision in which a person has the right to purchase real estate in the future.

\section{Pass-through taxation}

A taxation in which a business is not taxed directly on profits. Profits are "passed though" to the owners, and the owners report the amount on their personal tax returns. LLCs can elect pass-through taxation.

\section{Personal assets}

Assets that are owned by an individual, not a business. 


\section{Personal property}

Movable tangible items or intangible items that are owned by a person or business entity; not real property (land and anything attached to the land).

\section{Pierce the limited liability veil}

When a creditor shows that an LLC is not being operated as a separate legal business entity in order to claim the personal assets of owners in order to satisfy a debt or judgment.

\section{Present value}

The current value of assets or a future stream of cash flow given a specified rate of return.

\section{Probate}

The process in which the deceased person's debts are paid and remaining property is transferred to heirs and beneficiaries. If the deceased person had a will, the executor named in it presents the will for probate in court. If there was not a will, an administrator will be appointed to represent the estate.

\section{product liability}

\section{Product liability insurance}

Insurance coverage for claims or lawsuits resulting from the farm's products-for example, if a farm product was contaminated and caused food-borne illness.

\section{Productivity/efficiency}

Measures of the efficiency of production, maximizing the amount of output per unit of input.

\section{Property insurance}

Insurance coverage for damage to farm buildings, machinery, equipment, fixtures, products, or other items that should be covered. Damage could result from weather, theft, vandalism, and so on.

\section{Rate of return}

The gain or loss from an investment over a specified time period, expressed as a percentage of the investment's initial cost. 


\section{Real property}

Land and anything growing on, attached to, or built on it, except anything that can be severed without damage to the land (such as a crop that can be harvested).

\section{Realized value}

Value of an asset upon the sale of the asset.

\section{Right of first refusal}

A provision in a lease or other agreement that gives a designated party the right to buy a property before the seller negotiates any other offers. It may give the designated party the right to meet any other offers that are made on a property before a sale to an outside party.

\section{Rights of LLC members}

Financial rights such as sharing in the allocations of the LLC profits and losses, the right to a portion of remaining assets if the LLC dissolves, voting rights as defined in the operating agreement, inspection of LLC records, the right to sell the interest back to the LLC or other members (if closely held), or others defined in the operating agreement.

\section{Risk}

Events that keep a business from meeting its financial goals-for example, weather, accidents, labor markets, commodity markets, input costs, trade, regulatory changes, and so on.

\section{Secured transactions / secured debt / security interests / UCC-1}

Loans using personal property (not real property/land) as collateral on the debt.

\section{Securities law}

Laws that generally prohibit fraudulent business practices with the offer, purchase, or sales of securities such as ownership interests or equity positions in a business.

\section{Sole proprietorship}

A business entity in which one person operates a business for profit. The owner of a sole proprietorship does not have limited liability, so personal assets can be claimed to satisfy judgments or debts against the business. When a sole proprietor dies, the business assets (which are technically personal assets) are divided among the heirs with all other personal assets. 


\section{Survivorship}

The legal right established in joint ownership of property allowing the surviving owner of the property to take the interest of the person who has died automatically without going through probate. Exists when property is owned by joint tenants with rights or survivorship or by tenants by the entirety.

\section{Transfer on death (TOD)}

Designation that allows beneficiaries receive assets at the time of the owner's death without going through probate. It may be used on accounts, securities, and deeds in Oregon. Beneficiaries have no access to or control over the assets while the owner is alive.

\section{Trust}

A fiduciary arrangement that allows a third party or trustee to hold assets owned by the settlor on behalf of a beneficiary or beneficiaries. Assets held in a trust do not go through probate. Trusts can specify exactly how and when the assets pass to the beneficiaries. Trusts can be used for different purposes in estate planning and should be designed by an experienced estate-planning lawyer.

\section{Undercapitalized}

Holding insufficient funds to carry out the business purpose of the LLC. If an LLC is undercapitalized, the owners may be vulnerable to piercing the limited liability veil so that their personal assets are at risk in the event of a judgment or debt collection.

\section{Valuation method}

There are different ways to determine the value of the farm business, depending on the circumstances. The net balance sheet value is the current assets minus the liabilities. A liquidation approach would determine the value if all assets were sold and liabilities paid. The business can also be valued by calculating the present value of its earning potential over time or by looking at what similar businesses are selling for if they change ownership as a going concern.

\section{Workers' compensation insurance}

Insurance that covers injuries to employees that occur in the course of employment. Oregon requires all employers to carry workers' compensation insurance for all employees. Premiums are based on level of risk involved in the occupation. 


\section{Creative Commons License}

This work is licensed by Christy Anderson Brekke \& Joe Hobson (@2019) under a Attribution-NonCommercial-NoDerivatives 4.0 International (CC BY-NC-ND 4.0)

You are free to:

Share - copy and redistribute the material in any medium or format The licensor cannot revoke these freedoms as long as you follow the license terms.

\section{Under the following terms:}

Attribution - You must give appropriate credit, provide a link to the license, and indicate if changes were made. You may do so in any reasonable manner, but not in any way that suggests the licensor endorses you or your use.

NonCommercial - You may not use the material for commercial purposes. NoDerivatives - If you remix, transform, or build upon the material, you may not distribute the modified material. 


\section{Recommended Citations}

\section{APA (7th)}

Online:

Brekken, C., \& Hobson, J. (2019, January 1). Getting Organized. https://open.oregonstate.education/farmsuccession-planning/.

Print:

Brekken, C., \& Hobson, J. (2019). Getting Organized. Oregon State University.

\section{APA (6th)}

Online: Brekken, C., \& Hobson, J. (2019, January 01). Getting Organized. Retrieved [Retrieval date e.g. January 1, 2021], from https://open.oregonstate.education/farm-succession-planning/

Print:

Brekken, C., \& Hobson, J. (2019). Getting Organized. Corvallis, OR: Oregon State University.

\section{MLA (8th)}

Online:

Brekken, Cristy, and Hobson, Joe. Getting Organized. 1 Jan. 2019, https://open.oregonstate.education/ farm-succession-planning/. 
Print:

Brekken, Cristy and Hobson, Joe. Getting Organized. Oregon State University, 2019.

\section{$\operatorname{MLA}(7 \mathrm{th})$}

Online:

Brekken, Cristy, and Hobson, Joe. "Getting Organized." 01 Jan. 2019. Web. [Retrieval date e.g. 1 Jan. 2021].

Print:

Brekken, Cristy, and Hobson, Joe. Getting Organized. Corvallis: Oregon State U, 2018. Print.

\section{Chicago}

Online:

Brekken, Cristy, and Joe Hobson. "Getting Organized," January 1, 2019.

https://open.oregonstate.education/farm-succession-planning/.

Print:

Brekken, Cristy, and Joe Hobson,. Getting Organized. Corvallis, OR: Oregon State University, 2021. 


\section{Versioning}

This page provides a record of changes made to this publication. Each set of edits is acknowledged with a 0.01 increase in the version number. The exported files, available on the homepage, reflect the most recent version.

If you find an error in this text, please fill out the form at bit.ly/33cz3Q1

\begin{tabular}{|l|l|l|l|}
\hline Version & Date & Change Made & Location in text \\
\hline 0.1 & MM/DD/YYYY & & \\
\hline & & & \\
\hline & & & \\
\hline
\end{tabular}

